\title{
En route to phosphonato iridium(I) complexes: the decisive effect of an intramolecular hydrogen bondt¥
}

\author{
Vincenzo Passarelli, ${ }^{* a, b}$ Jesús J. Pérez-Torrente ${ }^{b}$ and Luis A. Oro ${ }^{b}$ \\ Pentacoordinated iridium(I) complexes of formula $\operatorname{IrCl}(\mathrm{SiNP})(\mathrm{tfbb}) \quad(\mathbf{1})$ and $\operatorname{IrCl}(\mathrm{HNP})_{2}(\mathrm{tfbb}) \quad(\mathbf{2}) \quad(\mathrm{SiNP} \quad=$ \\ $\left.\mathrm{SiMe}_{2}\left\{\mathrm{~N}\left(4-\mathrm{C}_{6} \mathrm{H}_{4} \mathrm{CH}_{3}\right) \mathrm{PPh}_{2}\right\}_{2} ; \mathrm{HNP}=\mathrm{NH}\left(4-\mathrm{C}_{6} \mathrm{H}_{4} \mathrm{CH}_{3}\right) \mathrm{PPh}_{2}\right)$ have been prepared and fully characterised. Both feature a \\ distorted square pyramidal coordination polyhedron at the metal centre in the solid state and are fluxional in solution. \\ Their reaction with trimethyl phosphite yields the derivatives $\left[\operatorname{Ir}(\operatorname{SiNP})\left\{\mathrm{P}(\mathrm{OMe})_{3}\right\}(\mathrm{tfbb})\right] \mathrm{Cl} \quad([3] \mathrm{Cl}) \quad$ and \\ $\operatorname{Ir}\left\{\mathrm{PO}(\mathrm{OMe})_{2}\right\}(\mathrm{HNP})_{2}(\mathrm{tfbb})(4)$. The course of the reaction between $\operatorname{IrCl}(\mathrm{HNP})_{2}(\mathrm{tfbb})(\mathbf{2})$ and trimethyl phosphite was \\ elucidated by NMR spectroscopy and DFT calculations, showing that the intermediate $\left[\operatorname{Ir}(\mathrm{HNP})_{2}\left\{\mathrm{P}(\mathrm{OMe})_{3}\right\}(\mathrm{tfbb})\right]^{+}\left(5^{+}\right)$forms \\ and further reacts with the chloride anion yielding the phosphonato derivative $\mathbf{4}$ and methyl chloride. The decisive role of \\ the $\mathrm{N}-\mathrm{H}$ group in the formation of the phosphonato ligand has been established by IR and NMR spectroscopic \\ measurements and by DFT calculations.
}

\section{INTRODUCTION}

In the last years bifunctional metal-ligand systems - metalligand systems containing at least one functional group in the backbone of the ligand - have attracted increasing interest. ${ }^{1}$ It has been shown that their ability to provide an extra site for non-covalent interactions of incoming substrates with the metal-ligand platform can be decisive in determining the outcome of both stoichiometric and catalytic reactions. Thus, both the elucidation of the elementary steps of the overall transformation and the detailed description of the interaction(s) of the incoming substrate with the metal-ligand platform have become a major issue in the investigation on bifunctional systems. $^{2}$ On this background, the metal complexes $\mathrm{I}^{3}$ and $\mathrm{II}^{4}$ containing an $\mathrm{N}$-heterocyclic carbene ligand with a $\beta-\mathrm{NH}$ group (Scheme 1 ) are particularly worth a mention. Indeed when I was used as catalyst in competitive hydrogenation tests of pentyl but-3-enoate vs. 1-dodecene, pentyl but-3-enoate was hydrogenated faster as a consequence of the proposed intermediate III featuring an intramolecular $\mathrm{NH} \cdots \mathrm{O}$ hydrogen bond. ${ }^{3}$ In addition, the facile dehydrative coupling of allyl alcohol and complex II affording $\mathbf{V}$ was proposed to take place via the intermediate IV stabilised by the interaction of allyl alcohol with both the metal centre and the $\beta-\mathrm{NH}$ group (Scheme 1$)^{4}$

On the other hand, we have recently reported pentacoordinated iridium(I) derivatives containing the $N, N^{\prime}-$

\footnotetext{
a. Centro Universitario de la Defensa, Ctra. Huesca s/n, ES-50090 Zaragoza, Spain. E-mail: passarel@unizar.es

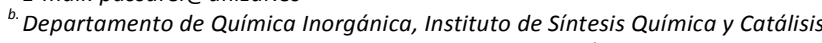
Homogénea (ISQCH), Universidad de Zaragoza-CSIC, C/ Pedro Cerbuna 12, ES50009 Zaragoza, Spain.

+ In memory of Professor Fausto Calderazzo for his outstanding contribution to Inorganic Chemistry.

¥ Electronic Supplementary Information (ESI) available: Selected NMR and kinetic data, views of the calculated structures along with selected bond lengths and angles, the cif file of structures $\operatorname{IrCl}(\mathrm{SiNP})(\mathrm{tfbb})(\mathbf{1}), \operatorname{IrCl}(\mathrm{HNP})_{2}(\mathrm{tfbb})(\mathbf{2})$, $\left[\operatorname{Ir}(\mathrm{SiNP})\left\{\mathrm{P}(\mathrm{OMe})_{3}\right\}(\mathrm{tfbb})\right] \mathrm{Cl}([3] \mathrm{Cl})$ and $\operatorname{Ir}\left\{\mathrm{PO}(\mathrm{OMe})_{2}\right\}(\mathrm{SiNP})(\mathrm{tfbb})(4)$, and atomic coordinates of calculated structures. See DOI: 10.1039/x0xx00000x
}

diphosphanosilanediamino

ligand SiNP $\left(\mathrm{SiNP}=\mathrm{SiMe}_{2}\left\{\mathrm{~N}\left(4-\mathrm{C}_{6} \mathrm{H}_{4} \mathrm{CH}_{3}\right) \mathrm{PPh}_{2}\right\}_{2}\right.$, Scheme 2). ${ }^{5}$ In particular, the synthesis of $\operatorname{IrCl}(\mathrm{SiNP})(\mathrm{cod})^{5 \mathrm{a}}$ was described along with the study of its reactivity with trimethyl phosphite ${ }^{5 b}$ (Scheme 3 ) showing the reversible formation of the intermediate cation $\left[\operatorname{Ir}(\mathrm{SiNP})\left\{\mathrm{P}(\mathrm{OMe})_{3}\right\}(\mathrm{cod})\right]^{+}$that affords the complexes $\left[\mathrm{IrH}(\mathrm{SiNP}-\mathrm{H})\left\{\mathrm{P}(\mathrm{OMe})_{3}\right\}_{2}\right] \mathrm{Cl}$ and $\operatorname{IrHCl}(\mathrm{SiNP}-\mathrm{H})\left\{\mathrm{P}(\mathrm{OMe})_{3}\right\}$ as a result of an intramolecular $\mathrm{C}-\mathrm{H}$ oxidative addition (Scheme 3 ). On this background we decided to synthesize metal complexes containing either SiNP or the parent amino-phosphane HNP $\left(\mathrm{HNP}=\mathrm{NH}\left(4-\mathrm{C}_{6} \mathrm{H}_{4} \mathrm{CH}_{3}\right) \mathrm{PPh}_{2}\right.$, Scheme 2) in order to assess the influence of the $\mathrm{N}-\mathrm{H}$ group on the reactivity of the complexes. Thus, herein we report novel iridium(I) complexes containing SiNP or HNP ligands and the $\operatorname{lr}(\mathrm{tfbb})$ moiety (tfbb = tetrafluorobenzobarrelene), and the study of their reactivity with trimethyl phosphite showing the decisive role of the $\mathrm{N}-\mathrm{H}$ group in determining the outcome of the reaction.

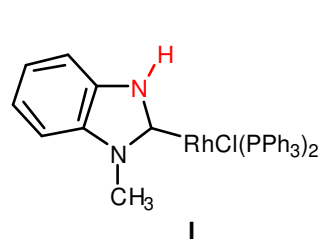<smiles>C=CCC(=O)OC1N(C)c2ccccc2N1C</smiles>

II

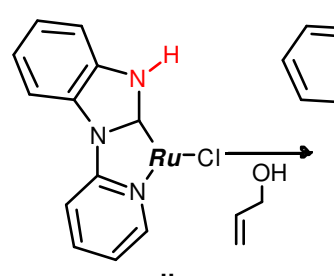

(c)
III<smiles></smiles>

$\boldsymbol{R} \boldsymbol{u}=\mathrm{RuCp} \mathrm{p}^{*}$

Scheme 1 


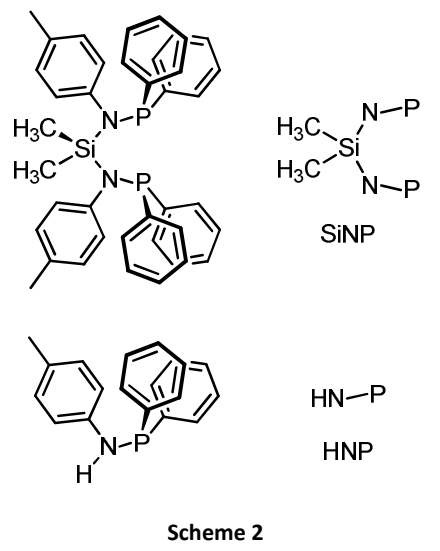

Scheme 2

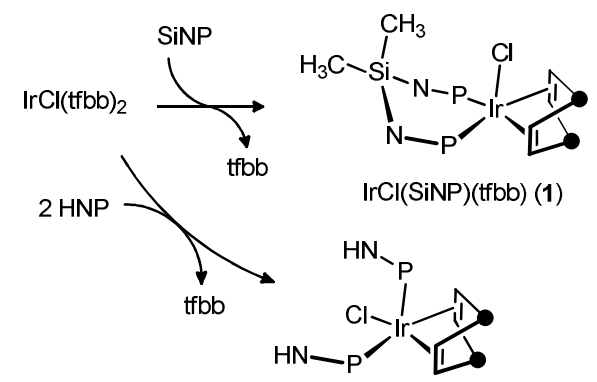

$\operatorname{IrCl}(\mathrm{HNP})_{2}(\mathrm{tfbb})(2)$

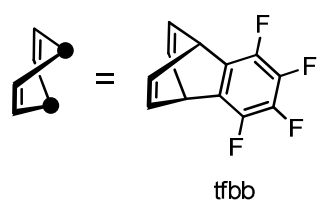

Scheme 4

\section{RESULTS AND DISCUSSION}

Synthesis of $\operatorname{IrCl}(\mathrm{SiNP})(\mathrm{tfbb})(\mathbf{1})$ and $\operatorname{IrCl}(\mathrm{HNP})_{2}$ (tfbb) (2). The reaction of $\mathrm{IrCl}(\mathrm{tfbb})_{2}$ with SiNP (1:1) or HNP (1:2) cleanly affords the pentacoordinated derivatives $\operatorname{IrCl}(\mathrm{SiNP})(\mathrm{tfbb})(\mathbf{1})$ and $\operatorname{IrCl}(\mathrm{HNP})_{2}(\mathrm{tfbb})$ (2) respectively (Scheme 4). Their solid state structures were determined by single crystal $\mathrm{X}$-ray diffraction. Views of the complexes and the coordination polyhedra are shown in Figure 1. Selected bond lengths and angles are given in Table 1.

In order to define the coordination polyhedron, the parameter $\tau=(\beta-\alpha) / 60$ proposed by Reedjik and Addison was used, ${ }^{6}$ where $\alpha$ and $\beta(\beta>\alpha)$ are the largest coordination angles. Given that $\tau$ ranges from 0 (ideal square pyramid) to 1 (ideal trigonal bipyramid), the values calculated for 1 (0.38) and for 2 (0.28) point out that both complexes display a distorted square pyramid arrangement at the metal center. In both complexes the tfbb ligand stays in the putative equatorial plane, displaying similar bite angles (1, 67.568(4) ${ }^{\circ}$; 2, $\left.67.053(11)^{\circ}\right)$. The coordination sphere of iridium is completed by a chlorido ligand either in the apical position in $\mathbf{1}$ or in the equatorial plane in $\mathbf{2}$ (Figure 1). The two remaining coordination sites are occupied by the phosphorus atoms from the SiNP (1) or the HNP ligands (2) thus rendering<smiles></smiles>
$\operatorname{IrCl}(\operatorname{SiNP})(\operatorname{cod})$

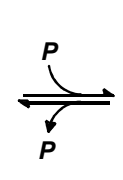

$[\operatorname{lr}(\mathrm{S}$

[Ir(SiNP) $\left.\left\{\mathrm{P}(\mathrm{OMe})_{3}\right\}(\mathrm{Cod})\right] \mathrm{Cl}$
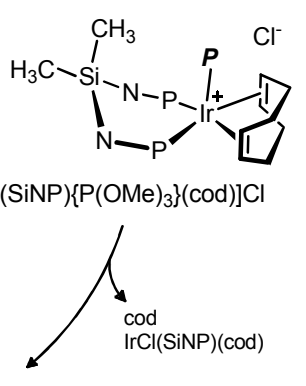

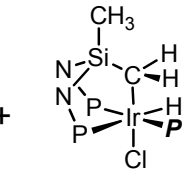

$\left[\mathrm{IrH}(\mathrm{SiNP}-\mathrm{H})\left\{\mathrm{P}(\mathrm{OMe})_{3}\right\}_{2}\right] \mathrm{Cl} \quad \operatorname{IrHCl}(\mathrm{SiNP}-\mathrm{H})\left\{\mathrm{P}(\mathrm{OMe})_{3}\right\}$ the SPY $-5-13^{7}$ configuration for 1 and the SPY-5-23 configuration for $\mathbf{2}$. In both cases the $\mathrm{P}-\mathrm{Ir}-\mathrm{Cl}$ angles are close to $90^{\circ}\left(\mathbf{1}, 94.8^{\circ}\right.$ av.; $2,89.7^{\circ}$ av.). Nevertheless, it should be noted that the $P(1)-\operatorname{Ir}(1)-P(2)$ angle in the HNP derivative 2 $\left(100.37(4)^{\circ}\right)$ is wider than the bite angle of the ligand SiNP in complex $1\left(92.39(3)^{\circ}\right)$ as determined by the six membered ring IrP $\mathrm{N}_{2} \mathrm{Si}$. In both complexes typical Ir-P, Ir-C and Ir-Cl bond lengths are observed. ${ }^{8}$ Even so, the olefinic carbon-carbon bond lengths $C(1)-C(2)$ and $C(4)-C(5)$ (Table 1 ) are significantly different in both $\mathbf{1}$ and $\mathbf{2}$ indicating that the more elongated $C(1)-C(2)$ bond undergoes a higher $\pi$-back donation than the shorter $C(4)-C(5)$ bond. ${ }^{9}$ Accordingly the $\operatorname{Ir}(1)-C(1)$ and $\operatorname{Ir}(1)-$ $C(2)$ bond lengths are shorter than the $\operatorname{Ir}(1)-C(4)$ and $\operatorname{Ir}(1)-C(5)$

Table 1. Selected bond lengths (Å) and angles $\left({ }^{\circ}\right)$ of $\operatorname{IrCl}(\mathrm{SiNP})(\mathrm{tfbb})(\mathbf{1})$ and $\operatorname{IrCl}(\mathrm{HNP})_{2}(\mathrm{tfbb})(\mathbf{2})$. $^{*}$

\begin{tabular}{|c|c|c|}
\hline & $\operatorname{IrCl}(\operatorname{SiNP})(\mathrm{tfbb})(\mathbf{1})$ & $\operatorname{IrCl}(\mathrm{HNP})_{2}(\mathrm{tfbb})(2)$ \\
\hline $\operatorname{Ir}(1)-C(1)$ & $2.132(3)$ & $2.123(4)$ \\
\hline $\operatorname{Ir}(1)-C(2)$ & $2.129(3)$ & $2.081(4)$ \\
\hline $\operatorname{Ir}(1)-\operatorname{ct}[1-2]$ & $2.00741(13)$ & $1.9719(2)$ \\
\hline $\operatorname{Ir}(1)-C(4)$ & $2.259(3)$ & $2.286(4)$ \\
\hline $\operatorname{Ir}(1)-C(5)$ & $2.242(3)$ & $2.285(4)$ \\
\hline $\operatorname{Ir}(1)-\operatorname{ct}[4-5]$ & $2.14250(14)$ & $2.1789(2)$ \\
\hline$C(1)-C(2)$ & $1.429(4)$ & $1.456(5)$ \\
\hline$C(4)-C(5)$ & $1.377(4)$ & $1.381(6)$ \\
\hline $\operatorname{Ir}(1)-P(1)$ & $2.2998(7)$ & $2.3421(10)$ \\
\hline $\operatorname{Ir}(1)-P(2)$ & $2.2754(7)$ & $2.2761(11)$ \\
\hline $\operatorname{lr}(1)-\mathrm{Cl}(1)$ & $2.5162(7)$ & $2.5279(10)$ \\
\hline$P(1)-\operatorname{Ir}(1)-P(2)$ & $92.39(3)$ & $100.37(4)$ \\
\hline$P(1)-\operatorname{Ir}(1)-C l(1)$ & $98.96(2)$ & $90.77(3)$ \\
\hline$P(2)-\operatorname{Ir}(1)-C I(1)$ & $90.68(2)$ & $88.70(4)$ \\
\hline $\operatorname{ct}[1-2]-\operatorname{Ir}(1)-P(1)$ & $142.701(18)$ & $126.83(3)$ \\
\hline $\operatorname{ct}[4-5]-\operatorname{Ir}(1)-P(1)$ & $96.120(18)$ & $100.78(3)$ \\
\hline $\operatorname{ct}[1-2]-\operatorname{Ir}(1)-P(2)$ & $98.538(19)$ & $94.28(3)$ \\
\hline $\operatorname{ct}[4-5]-\operatorname{Ir}(1)-P(2)$ & $165.263(19)$ & $157.65(3)$ \\
\hline $\operatorname{ct}[1-2]-\operatorname{Ir}(1)-\mathrm{Cl}(1)$ & $116.342(18)$ & $140.72(2)$ \\
\hline $\operatorname{ct}[4-5]-\operatorname{Ir}(1)-\mathrm{Cl}(1)$ & $99.816(17)$ & $98.16(2)$ \\
\hline $\operatorname{ct}[1-2]-\operatorname{Ir}(1)-\operatorname{ct}[4-5]$ & $67.568(4)$ & $67.053(11)$ \\
\hline
\end{tabular}

* $\operatorname{ct}[\mathrm{X}-\mathrm{Y}]$ : centroid of the $\mathrm{C}(\mathrm{X})-\mathrm{C}(\mathrm{Y})$ bond. 


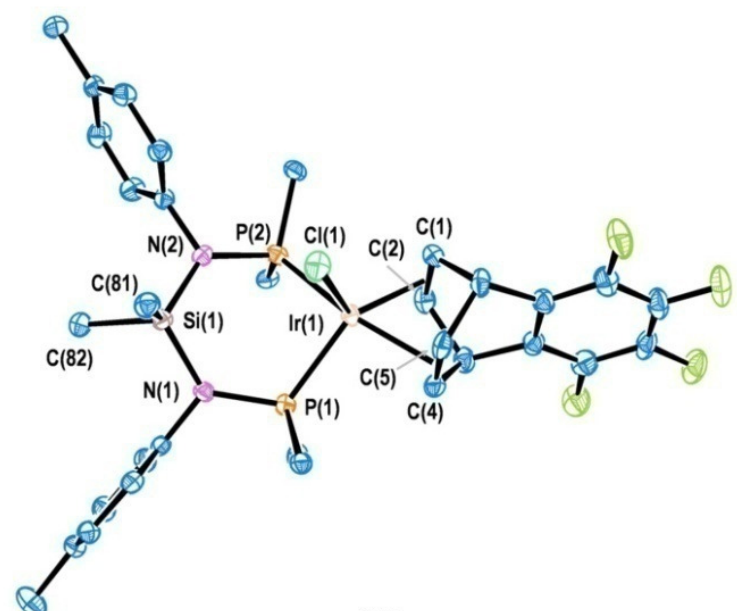

(A)

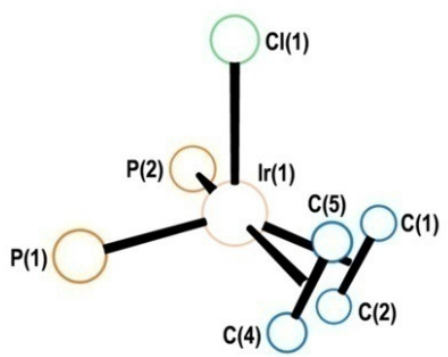

(C)

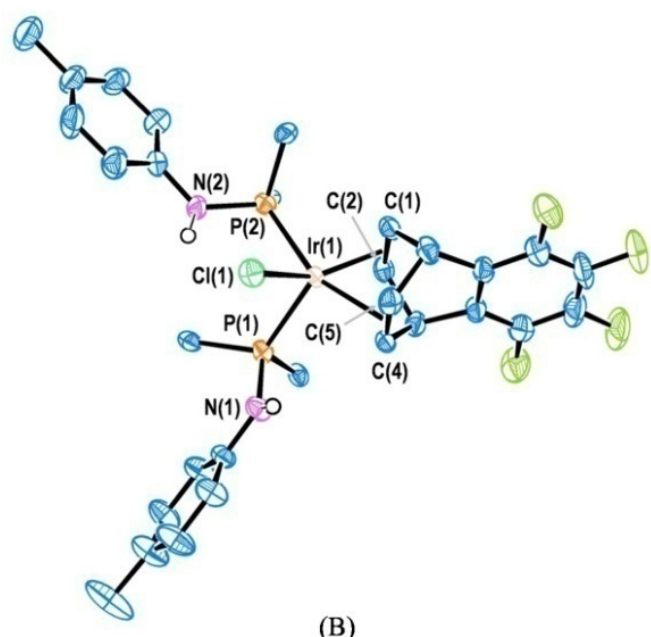

(B)

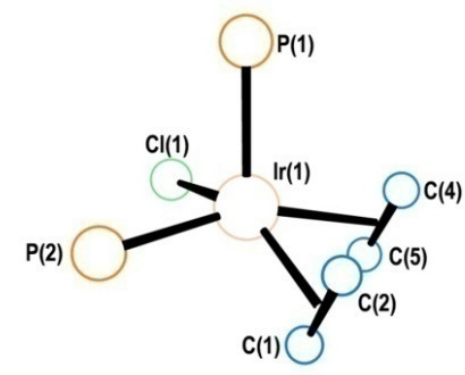

(D)

Figure 1. ORTEP view of (A) $\operatorname{IrCl}(\operatorname{SiNP})(\mathrm{tfbb})(\mathbf{1})$ and $(\mathrm{B}) \operatorname{IrCl}(\mathrm{HNP})_{2}(\mathrm{tfbb})(\mathbf{2})$. Ellipsoids are at the $50 \%$ of probability. Only ipso carbons are shown and hydrogen atoms, except those of the N-H group, are omitted for clarity. (B) View of the coordination polyhedra of (C) $\operatorname{IrCl}(\mathrm{SiNP})(\mathrm{tfbb})(\mathbf{1})$ and $(\mathrm{D}) \operatorname{IrCl}(\mathrm{HNP})_{2}(\mathrm{tfbb})(\mathbf{2})$.

ones (Table 1). Finally, a boat conformation is observed for the six membered ring $\mathrm{SiN}_{2} \mathrm{P}_{2} \mathrm{Ir}$, similar to that reported for the structurally characterised rhodium derivative $\mathrm{RhCl}_{2}\left(\mathrm{C}_{3} \mathrm{H}_{5}\right)(\mathrm{SiNP})^{10}$ and proposed for related iridium complexes based on DFT-B3LYP calculations. ${ }^{5}$

Solution behaviour of $\operatorname{IrCl}(\mathrm{SiNP})(\mathrm{tfbb})(\mathbf{1})$ and $\operatorname{IrCl}(\mathrm{HNP})_{2}$ (tfbb) (2). The NMR spectra of $\mathbf{1}$ and $\mathbf{2}$ indicate that their solid state structures are maintained in solution although both complexes exhibit a fluxional behaviour. Indeed as far as $\operatorname{IrCl}(\mathrm{SiNP})(\mathrm{tfbb})$ (1) is concerned, one ${ }^{31} \mathrm{P}$ singlet at $47.2 \mathrm{ppm}$ and two ${ }^{19} \mathrm{~F}$ multiplets at -148.8 and $-162.2 \mathrm{ppm}$ are observed at room temperature. Also, the ${ }^{1} \mathrm{H}$ NMR spectrum contains a broad resonance for the $\mathrm{SiMe}_{2}$ moiety and two signals at 4.78 and

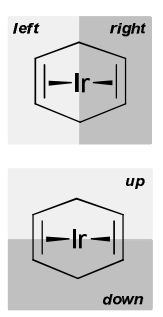

(A)
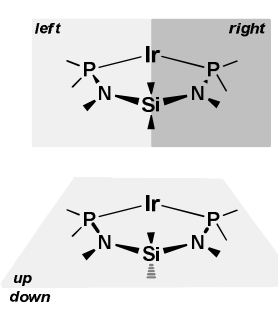

(B)
Figure 2. Left and right and up and down semispaces at the coordinated $\mathrm{tfbb}(\mathrm{A})$ and at the coordinated SiNP ligand (B).
$2.39 \mathrm{ppm}$ for averaged $\mathrm{C}^{\mathrm{sp} 2} \mathrm{H}$ and $\mathrm{C}^{\mathrm{sp} 3} \mathrm{H}$ moieties, respectively, of the tfbb ligand. On these bases the up and down and the left and right semispaces both at the tfbb and the SiNP ligands (Figure 2) are equivalent or exchanged by a rapid process. As a confirmation, at $183 \mathrm{~K}$ one broad ${ }^{31} \mathrm{P}$ resonance (48.1 ppm, $\Delta v_{1 / 2}=30.1 \mathrm{~Hz}$, see ESI-Figure S1) is observed indicating that even at that temperature the left and right semispaces at the SiNP ligand are exchanging although at a slower rate than at room temperature. On the other hand, at $183 \mathrm{~K}$ two ${ }^{1} \mathrm{H}$ signals are observed for the $\mathrm{SiMe}_{2}$ moiety $(1.05,-0.55 \mathrm{ppm})$ pointing out that the up and down semispace at the SiNP are nonequivalent. As far as the tfbb ligand is concerned, at $183 \mathrm{~K}$ four ${ }^{19} \mathrm{~F}$ resonances are observed at $-147.6,-147.8,-160.7$, $-161.1 \mathrm{ppm}$ (see ESI-Figure S1) indicating that the up and down semispaces at the tfbb ligand are non-equivalent, as well. In addition, (i) two ${ }^{1} \mathrm{H}$ resonances for the two $\mathrm{C}^{\mathrm{sp} 3} \mathrm{H}$ hydrogens (5.14 and $4.56 \mathrm{ppm}$ ) and (ii) two resolved (although broad) ${ }^{1} \mathrm{H}$ resonances for the four $\mathrm{C}^{\mathrm{sp} 2} \mathrm{H}$ hydrogens (2.48 and $2.05 \mathrm{ppm}$ ) are observed confirming that the up and down semispaces at the tfbb ligand are non-equivalent and that, similar to SiNP, the left-right semispace should be rapidly exchanging even at $183 \mathrm{~K}$. For the sake of comparison, the molecular structure of $\operatorname{IrCl}(\mathrm{SiNP})(\mathrm{tfbb})$ (1) in $\mathrm{CH}_{2} \mathrm{Cl}_{2}$ was calculated at the DFT-B3LYP level (see ESI-Figure S4 and Table 
S2) ${ }^{*}$ and the minimum free energy structure was found to be very similar (SPY-5-13, $\tau=0.42$ ) to the solid state structure of 1. A similar distorted SPY-5-13 configuration was already reported for the cod derivative $\operatorname{IrCl}(\mathrm{SiNP})(\operatorname{cod}) .{ }^{5 \mathrm{~b}}$

With regard to $\operatorname{IrCl}(\mathrm{HNP})_{2}(\mathrm{tfbb})(2)$, the ${ }^{1} \mathrm{H},{ }^{19} \mathrm{~F}$ and ${ }^{31} \mathrm{P} N M R$ spectra at room temperature are indicative both of two equivalent HNP ligands and of up-and-down and left-andright equivalent semispaces at the tfbb ligand. Further, no significant changes in the spectra were observed over the temperature range $220-298 \mathrm{~K}\left(\mathrm{CDCl}_{3}\right)$. Nevertheless, the minimum free energy structure calculated for $\mathbf{2}$ at the DFTB3LYP level in solution is similar to that of the solid state, i.e. it contains non-equivalent HNP ligands and features nonequivalent up-and-down and left-and-right semispaces at the tfbb ligand (SPY-5-23, $\tau=0.36$, see ESI-Figure S5 and Table S3). Thus, 2 should be fluxional in solution and rapid process(es) should take place even at $220 \mathrm{~K}$ rendering equivalent HNP ligands and exchanging the up and down and the left and right semispaces at the tfbb ligand. ${ }^{\dagger}$ Finally it should be noted that the ${ }^{1} \mathrm{H}$ signal of the $\mathrm{NH}$ group is observed at $6.44 \mathrm{ppm}(4.37$ ppm in uncomplexed HNP). ${ }^{5 b}$

Synthesis of $\left[\operatorname{Ir}(\operatorname{SiNP})\left\{\mathrm{P}(\mathrm{OMe})_{3}\right\}(\mathrm{tfbb})\right] \mathrm{Cl}$ (3). The reaction of $\operatorname{IrCl}(\mathrm{SiNP})(\mathrm{tfbb})(\mathbf{1})$ with trimethyl phosphite cleanly affords the salt $\left[\operatorname{Ir}(\mathrm{SiNP})\left\{\mathrm{P}(\mathrm{OMe})_{3}\right\}(\mathrm{tfbb})\right] \mathrm{Cl}([3] \mathrm{Cl})$ (Scheme 5). The solid state structure of the cation $\mathbf{3}^{+}$is shown in Figure 3 and selected bond lengths and angles are given in Table 2 . The coordination polyhedron at iridium is a distorted square pyramid (SPY-5-13, $\tau=0.33$ ) with the trimethyl phosphito ligand in the apical position, and the tfbb (bite angle $\left.65.309(9)^{\circ}\right)$ and the SiNP ligands $\left(P(1)-\operatorname{Ir}(1)-P(2) 92.84(5)^{\circ}\right)$ occupying the equatorial coordination sites. Similarly to $\mathbf{1}$, iridium-carbon and olefinic carbon-carbon bond lengths in the tfbb ligand suggest a higher $\pi$-back donation to the $C(1)-C(2)$ bond than to the $C(4)-C(5)$ one (Table 2$).{ }^{9}$

Fluxional behaviour of $\left[\operatorname{Ir}(\mathrm{SiNP})\left\{\mathrm{P}(\mathrm{OMe})_{3}\right\}(\mathrm{tfbb})\right]^{+} \quad\left(3^{+}\right)$. Compound $\mathbf{3}^{+}$is fluxional in solution as evidenced by its NMR spectra, and dynamic processes are operative exchanging the up and down and the left and right semispaces both at the SiNP and the tfbb ligands. Indeed the $A X_{2}$ pattern observed in the ${ }^{31} \mathrm{P} N M R$ spectrum at $298 \mathrm{~K}(82.5 \mathrm{ppm}$, triplet; $39.3 \mathrm{ppm}$, doublet; ${ }^{2} J_{\mathrm{PP}}=7.2 \mathrm{~Hz}$ ) confirms that both phosphorus atoms of

Scheme 5

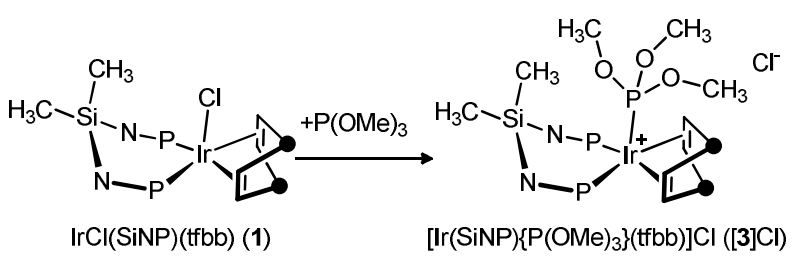

the SiNP ligand coordinate the metal centre but indicates that the left and right semispaces at SiNP are equivalent or

\footnotetext{
* Selected experimental and calculated NMR data $\left(183 \mathrm{~K}, \mathrm{CD}_{2} \mathrm{Cl}_{2}\right)$ for $1: \delta_{\mathrm{H} \text { exp }}\left(\delta_{\mathrm{H} \text { calc }}\right)=$ $5.14\left(4.99, \mathrm{C}^{\mathrm{sp} 3} \mathrm{H}^{\mathrm{tfbb}}, 1 \mathrm{H}\right), 4.14\left(4.56, \mathrm{C}^{\mathrm{sp} 3} \mathrm{H}^{\mathrm{tfbb}}, 1 \mathrm{H}\right), 2.73\left(2.48, \mathrm{C}^{\mathrm{sp} 2} \mathrm{H}^{\mathrm{tfbb}}, 2 \mathrm{H}\right.$ av. $), 2.46$ $\left(2.05, \mathrm{C}^{\mathrm{sp} 2} \mathrm{H}^{\mathrm{tfbb}}, 2 \mathrm{H}\right.$ av. $), 2.09\left(1.99, \mathrm{CH}_{3}{ }^{\text {tol }}\right), 1.05\left(1.08, \mathrm{SiCH}_{3}\right),-0.55\left(-0.63, \mathrm{SiCH}_{3}\right) ; \delta_{\text {exp }}$ $\left(\delta_{\text {falc }}\right)=-147.6(-146.5),-147.8(-147.1),-160.7(-161.7),-161.1(-161.9)$.

${ }^{+}$Selected experimental and calculated NMR data $\left(298 \mathrm{~K}, \mathrm{CDCl}_{3}\right)$ for 2: $\delta_{\mathrm{H} \text { exp }}\left(\delta_{\mathrm{H} \text { calc }}\right)=$ $6.44(6.49, \mathrm{NH}), 5.07\left(4.65, \mathrm{C}^{\mathrm{sp} 3} \mathrm{H}^{\mathrm{tfbb}}, 2 \mathrm{H}\right.$ av. $), 2.41\left(2.54, \mathrm{C}^{\mathrm{sp} 2} \mathrm{H}^{\mathrm{tfbb}}, 4 \mathrm{H}\right.$ av.), 2.12 (2.16, $\left.\mathrm{CH}_{3}{ }^{\text {tol }}\right) ; \delta_{\text {exp }}\left(\delta_{\text {falc }}\right)=-147.7(-146.7,2 \mathrm{~F} \mathrm{av}),.-160.5(-161.5,2 \mathrm{~F} \mathrm{av}$.$) .$
}

averaged by a rapid fluxional process. Accordingly, the ${ }^{1} \mathrm{H}$ and ${ }^{13} \mathrm{C}$ spectra show equivalent tolyl groups. Additionally, the methyls of the $\mathrm{SiMe}_{2}$ moiety are non-equivalent $\left(\delta_{\mathrm{H}}, \delta_{\mathrm{C}}: 0.79\right.$, $3.03 ;-0.38,4.81 \mathrm{ppm})$ thus suggesting that the up and down semispaces at the SiNP are non-equivalent. In addition, given that two ${ }^{19} \mathrm{~F}$ signals $(-146.08,-158.59 \mathrm{ppm})$, one ${ }^{1} \mathrm{H}$ signal for the $\mathrm{C}^{\mathrm{sp} 2} \mathrm{H}$ hydrogens $(2.67 \mathrm{ppm})$ and one for the $\mathrm{C}^{\mathrm{sp} 3} \mathrm{H}$ hydrogens (4.76 ppm) are observed for the tfbb ligand at 298 $\mathrm{K}$, both the up and down and the left and right semispaces are equivalent or averaged.

In order to elucidate the overall fluxional behaviour of $\mathbf{3}^{+}$, a variable temperature NMR study was undertaken. At $183 \mathrm{~K}$ $\left(\mathrm{CD}_{2} \mathrm{Cl}_{2}\right)$ an $\mathrm{AXY}$ pattern was observed in the ${ }^{31} \mathrm{P} \mathrm{NMR}$ spectrum (83.0 ppm, dd, ${ }^{2} J_{\mathrm{PP}}=42.7,37.5 \mathrm{~Hz}, \mathrm{POCH}_{3} ; 41.3 \mathrm{ppm}, \mathrm{dd},{ }^{2} J_{\mathrm{PP}}=$

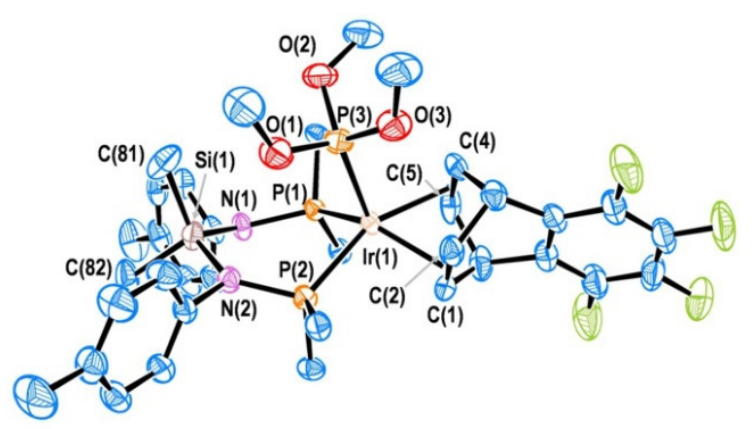

(A)

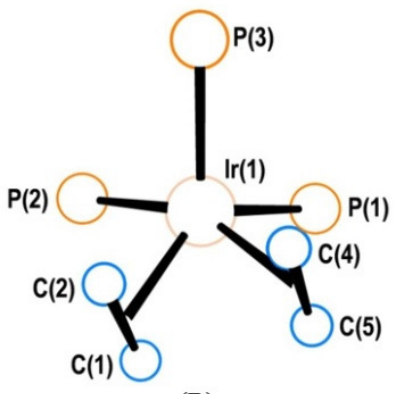

(B)

Figure 3. (A) ORTEP view of $\left[\operatorname{Ir}(\operatorname{SiNP})\left\{\mathrm{P}(\mathrm{OMe})_{3}\right\}(\mathrm{tfbb})\right]^{+}\left(\mathbf{3}^{+}\right)$in [3]Cl. Ellipsoids are at the $50 \%$ of probability. Only ipso carbons are shown and hydrogen atoms are omitted for clarity. (B) View of the coordination polyhedron of $3^{+}$.

Table 2. Selected bond lengths $(\AA)$ and angles $\left({ }^{\circ}\right)$ of $\left[\operatorname{Ir}(\operatorname{SiNP})\left\{\mathrm{P}(\mathrm{OMe})_{3}\right\}(\mathrm{tfbb})\right] \mathrm{Cl}$ ([3]Cl).*

$\begin{array}{llll}\operatorname{Ir}(1)-\mathrm{C}(1) & 2.179(6) & \mathrm{O}(2)-\mathrm{P}(3) & 1.589(4) \\ \operatorname{Ir}(1)-\mathrm{C}(2) & 2.166(5) & \mathrm{O}(3)-\mathrm{P}(3) & 1.589(4) \\ \operatorname{Ir}(1)-\mathrm{ct}[1-2] & 2.0516(3) & \mathrm{P}(1)-\operatorname{Ir}(1)-\mathrm{P}(2) & 92.84(5) \\ \operatorname{Ir}(1)-\mathrm{C}(4) & 2.285(5) & \mathrm{P}(1)-\operatorname{Ir}(1)-\mathrm{P}(3) & 102.94(5) \\ \operatorname{Ir}(1)-\mathrm{C}(5) & 2.290(6) & \mathrm{P}(2)-\operatorname{Ir}(1)-\mathrm{P}(3) & 98.25(5) \\ \operatorname{Ir}(1)-\mathrm{ct}[4-5] & 2.1839(3) & \mathrm{ct}[1-2]-\operatorname{Ir}(1)-\mathrm{P}(1) & 137.38(4) \\ \mathrm{C}(1)-\mathrm{C}(2) & 1.430(9) & \mathrm{ct}[4-5]-\operatorname{Ir}(1)-\mathrm{P}(1) & 96.29(3) \\ \mathrm{C}(5)-\mathrm{C}(4) & 1.360(9) & \mathrm{ct}[1-2]-\operatorname{Ir}(1)-\mathrm{P}(2) & 93.98(4) \\ \operatorname{Ir}(1)-\mathrm{P}(1) & 2.3372(13) & \mathrm{ct}[4-5]-\operatorname{Ir}(1)-\mathrm{P}(2) & 157.09(4) \\ \operatorname{Ir}(1)-\mathrm{P}(2) & 2.3001(14) & \mathrm{ct}[1-2]-\operatorname{Ir}(1)-\mathrm{P}(3) & 117.53(4) \\ \operatorname{Ir}(1)-\mathrm{P}(3) & 2.3173(15) & \mathrm{ct}[4-5]-\operatorname{Ir}(1)-\mathrm{P}(3) & 100.10(4) \\ \mathrm{O}(1)-\mathrm{P}(3) & 1.581(5) & \mathrm{ct}[4-5]-\operatorname{Ir}(1)-\mathrm{Ct}[1-2] & 65.309(9)\end{array}$

${ }^{*} \operatorname{ct}[\mathrm{X}-\mathrm{Y}]$ : centroid of the $\mathrm{C}(\mathrm{X})-\mathrm{C}(\mathrm{Y})$ bond. 
42.7, $32.7 \mathrm{~Hz}, \mathrm{P}^{1}$, SiNP; $36.8 \mathrm{ppm}, \mathrm{dd},{ }^{2} \mathrm{~J}_{\mathrm{PP}}=37.5,32.7 \mathrm{~Hz}, \mathrm{P}^{2}$, SiNP, see ESI-Figure S2) indicating that the left and right semispaces at SiNP are non-equivalent. Further the line shape analysis over the temperature range 183-233 $\mathrm{K}$ allowed the determination of the activation parameters of the left-right exchange at SiNP: $\Delta \mathrm{H}^{\ddagger}=48.1 \pm 0.5 \mathrm{~kJ} \cdot \mathrm{mol}^{-1} ; \Delta \mathrm{S}^{\ddagger}=48.0 \pm 2.5$ $\mathrm{J} \cdot \mathrm{mol}^{-1} \cdot \mathrm{K}^{-1}$ (see ESI-Table S1 and Figure S3). Despite the positive -although small- value of $\Delta \mathrm{S}^{\ddagger}$, the small value of $\Delta \mathrm{H}^{\ddagger}$, along with the above mentioned non-equivalence of the $\mathrm{SiMe}_{2}$ methyls at room temperature, strongly support that the leftright exchange should be non-dissociative. Indeed a dissociative pathway involving the reversible dissociation of one iridium-phosphorus bond should average also the $\mathrm{SiMe}_{2}$ methyls.

On this background, the structure of $\mathbf{3}^{+}$was calculated ${ }^{\ddagger}$ in $\mathrm{CH}_{2} \mathrm{Cl}_{2}$ and the minimum free energy structure was found to be similar to that of the solid state (See ESI-Figure S6 and Table S4) with a severely distorted SPY-5-13 arrangement $(\tau=0.48)$ of the donor atoms at the iridium centre. Given that a similar structure has previously been reported for $\left[\operatorname{Ir}(\mathrm{SiNP})\left\{\mathrm{P}(\mathrm{OMe})_{3}\right\}(\mathrm{cod})\right]^{+}$and that for this cation a nondissociative conformational equilibrium was shown to account for the left-right exchange at the SiNP ligand, ${ }^{5 a}$ reasonably a similar process, as shown in Scheme 6, could afford the leftright exchange of the SiNP ligand in $3^{+}$.

The ${ }^{19} \mathrm{~F}$ NMR spectrum at $183 \mathrm{~K}$ shows an $\mathrm{ABX}_{2}$ pattern of broad signals $\left(-146.7,1 \mathrm{~F} ;-146.1,1 \mathrm{~F} ;-159.1 \mathrm{ppm}, 2 \mathrm{~F} ; \Delta \mathrm{v}_{1 / 2}=\right.$ $70 \mathrm{~Hz}$ ) suggesting that the up-down exchange of the tfbb ligand is still operative at $183 \mathrm{~K}$. In addition, the ${ }^{1} \mathrm{H}$ NMR spectrum of $\mathbf{3}^{+}$at $183 \mathrm{~K}$ showed very broad and unresolved signals, which made it unsuitable for carrying out a reliable assignation of the signals and eventually for undertaking either ${ }^{1} \mathrm{H}-{ }^{1} \mathrm{H}$ EXSY measurements or ${ }^{1} \mathrm{H}$ line shape analysis. Thus, the additional processes contributing to the dynamic behaviour of $\mathbf{3}^{+}$in solution could not be identified.

Reaction of $\operatorname{IrCl}(\mathrm{HNP})(\mathrm{SiNP})$ (2) with trimethyl phosphite. At variance with $1, \quad \operatorname{IrCl}(\mathrm{HNP})_{2}(\mathrm{tfbb})$ (2) reacts with trimethyl phosphite yielding the phosphonato complex $\operatorname{Ir}\left\{\mathrm{PO}(\mathrm{OMe})_{2}\right\}(\mathrm{HNP})_{2}(\mathrm{tfbb})$ (4) (Scheme 7). Its solid state molecular structure is shown in Figure 4 and Table 3 contains a selection of bond lengths and angles. To the best of our

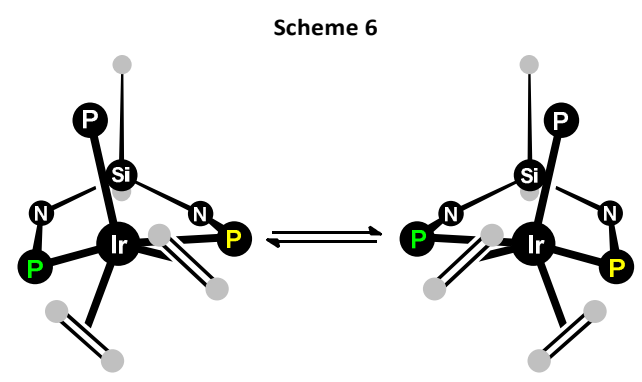

knowledge only two iridium(III) complexes featuring the

${ }^{\ddagger}$ Selected experimental and calculated NMR data $\left(\mathrm{CD}_{2} \mathrm{Cl}_{2}\right)$ for $3^{+}: \delta_{\mathrm{H}} \exp 298 \mathrm{~K}\left(\delta_{\mathrm{H}}\right.$ alc $)=3.88$ $\left(3.74, \mathrm{POCH}_{3}\right), 4.76\left(4.77, \mathrm{C}^{\mathrm{sp} 3} \mathrm{H}^{\mathrm{tfbb}}, 2 \mathrm{H}\right.$ av. $), 2.67\left(3.10, \mathrm{C}^{\mathrm{sp} 2} \mathrm{H}^{\mathrm{tfbb}}, 4 \mathrm{H}\right.$ av. $), 2.16(2.09$, $\left.\mathrm{CH}_{3}{ }^{\text {tol }}\right), 0.79\left(0.89, \mathrm{SiCH}_{3}\right),-0.38\left(-0.49, \mathrm{SiCH}_{3}\right) ; \delta_{\text {Fexp } 183 \mathrm{~K}}\left(\delta_{\text {F calc }}\right)=-146.7(-145.3,1 \mathrm{~F}),-$ $146.1(-145.9,1 \mathrm{~F}),-159.1(-159.9,2 \mathrm{~F}$ av. $) ; \delta_{\mathrm{p} \operatorname{exp~} 183 \mathrm{~K}}\left(\delta_{\mathrm{p} \text { calc }}\right)=83.0\left(77.2, \mathrm{P}(\mathrm{OMe})_{3}\right), 41.3$ (52.1, 1P, SiNP), $36.8(31.8,1 \mathrm{P}, \mathrm{SiNP})$. $\kappa \mathrm{P}-\mathrm{PO}(\mathrm{OMe})_{2}$ ligand have been structurally characterised so far, namely $\left[\mathrm{IrCp} *\left\{\kappa P-\mathrm{PO}(\mathrm{OMe})_{2}\right\}\left\{\kappa^{2} S, S^{\prime}-\left(\mathrm{SPPh}_{2}\right)_{2} \mathrm{CH}_{2}\right\}\right]\left[\mathrm{BF}_{4}\right]^{11}$ and $\quad \operatorname{IrCp} *\left\{\kappa P-P O(O M e)_{2}\right\}\left(\mu-\mathrm{C}_{3} \mathrm{H}_{3} \mathrm{~N}_{2}\right)\left\{\mu-\kappa^{2} P O-\right.$ $\left.\mathrm{PO}(\mathrm{OMe})_{2}\right\} \mathrm{Rh}(\mathrm{cod}) .{ }^{12}$ In this respect it should be noted that $\mathbf{4}$ is the first iridium(I) phosphonato complex structurally characterised. For the sake of completeness, only three structurally characterised rhodium(I) complexes have been reported so far, although all of them contain a $\kappa^{2} P, O-P O(O M e)_{2}$ ligand as a bridging moiety between two rhodium centres. ${ }^{13}$

The coordination polyhedron of iridium in $\mathbf{4}$ is a distorted square pyramid $(\tau=0.13)$ with a SPY-5-23 configuration. Indeed, the apical position is occupied by one HNP ligand, with the second HNP ligand, the phosphonato moiety and tfbb at the basal positions. Similarly to $\mathbf{2}$, based on the olefinic carbon-carbon and the iridium-carbon bond lengths a higher degree of $\pi$-back donation to the $C(1)-C(2)$ bond with respect to the $C(4)-C(5)$ bond can be envisaged. ${ }^{9}$ As far as the $\mathrm{PO}(\mathrm{OMe})_{2}$ ligand is concerned, the $\mathrm{P}(3)-\mathrm{O}(3)$ bond length is shorter $(1.496(2) \AA)$ than the $\mathrm{P}(3)-\mathrm{O}(1)(1.622(2) \AA)$ and $\mathrm{P}(3)-\mathrm{O}(2)$ ones $(1.631(2) \AA)$, in agreement with a phosphorusoxygen double bond. In this respect it should be noted that similar phosphorus-oxygen bond lengths have been reported for the cation $\left[\mathrm{IrCp} *\left\{\kappa P-\mathrm{PO}(\mathrm{OMe})_{2}\right\}\left\{\kappa^{2} S, S^{\prime}-\left(\mathrm{SPPh}_{2}\right)_{2} \mathrm{CH}_{2}\right\}\right]^{+}$ (1.475(5), 1.621(6), 1.604(5) $\AA)^{11}$ and for the dinuclear complex IrCp* $\left\{\kappa P-P O(O M e)_{2}\right\}\left(\mu^{2}-C_{3} \mathrm{H}_{3} \mathrm{~N}_{2}\right)\left\{\mu, \kappa^{2} P O-P O(O M e)_{2}\right\} \mathrm{Rh}(\mathrm{cod})$ $\left(\kappa P-\mathrm{PO}(\mathrm{OMe})_{2}\right.$ moiety: $1.482(6), 1.607(4), 1.635(7) \AA$ A $) .{ }^{12}$ Interestingly an intramolecular $\mathrm{NH} \cdots \mathrm{OP}$ hydrogen bond is present in 4, namely between $\mathrm{N}(1)-\mathrm{H}(1 \mathrm{n})$ and $\mathrm{O}(3)-\mathrm{P}(3)$, with the $\mathrm{N} \cdots \mathrm{O}$ distance $\left(2.813(3) \AA\right.$ ) and the $\mathrm{N}-\mathrm{H}-\mathrm{O}$ angle $\left(166(3)^{\circ}\right)$ falling in the ranges considered diagnostic of an $\mathrm{NH} \cdots \mathrm{O}$ hydrogen bond. ${ }^{14}$ An additional $\mathrm{NH} \cdots \mathrm{OP}$ short contact ( $\mathrm{N} \cdots \mathrm{O}$ $\left.3.108(5) \AA, \mathrm{N}-\mathrm{H}-\mathrm{O} 157(3)^{\circ}\right)$ has been observed between $\mathrm{N}(2)-\mathrm{H}(2 \mathrm{n})$ and $\mathrm{O}(1)-\mathrm{P}(3)$, as well. Nevertheless, given that the interatomic distance $\mathrm{N} \cdots \mathrm{O}$ is in the very upper limit for known $\mathrm{NH} \cdots \mathrm{O}$ hydrogen bonds, this contact could be a consequence of the proximity of the HNP and $\mathrm{PO}(\mathrm{OMe})_{2}$ ligands imposed by their cis arrangement $\left(P(2)-\operatorname{Ir}(1)-P(3) 93.93(3)^{\circ}\right)$. It is worth mentioning that very few examples of intramolecular $\mathrm{NH} \cdots \mathrm{OP}$ hydrogen bonds in a metal complex have been described in the literature. ${ }^{15}$
Scheme 7

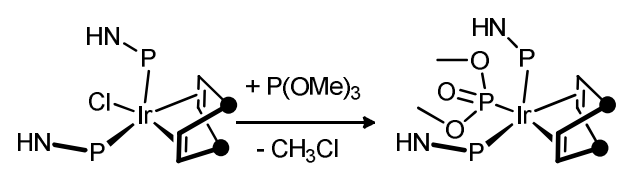

$\operatorname{IrCl}(\mathrm{HNP})_{2}(\mathrm{tfbb})(2)$
$\left[\operatorname{Ir}\left\{\mathrm{PO}(\mathrm{OMe})_{2}\right\}(\mathrm{HNP})_{2}(\mathrm{tfbb})(4)\right.$ 
The ${ }^{31} \mathrm{P}$ NMR spectrum of 4 at $298 \mathrm{~K}$ displays a $\mathrm{AM}_{2}$ pattern in agreement with the presence of the $\mathrm{PO}(\mathrm{OMe})_{2}$ group $(43.8$ ppm, triplet) and two HNP ligands (16.5 ppm, doublet, ${ }^{2} J_{\mathrm{PP}}=$ $36.3 \mathrm{~Hz}$ ), which are equivalent as a consequence of a fluxional process. Indeed, although the ${ }^{31} \mathrm{P}$ NMR spectrum still displays an $A M_{2}$ pattern at $190 \mathrm{~K}$, broad signals $\left(\Delta v_{1 / 2}=90 \mathrm{~Hz}\right)$ are observed suggesting that the two HNP ligands undergo an exchange process which is operative even at $190 \mathrm{~K}$. The ${ }^{1} \mathrm{H}$ NMR spectrum at $298 \mathrm{~K}$ shows the expected signal for the $\mathrm{PO}(\mathrm{OMe})_{2}$ ligand as a doublet at $3.58 \mathrm{ppm}\left({ }^{3} J_{\mathrm{HP}}=10.7 \mathrm{~Hz}\right)$ and the averaged signals for the two equivalent HNP ligands. In addition, the observation of two ${ }^{1} \mathrm{H}$ signals at 2.49 and 4.19 $\mathrm{ppm}$ and two ${ }^{19} \mathrm{~F}$ signals at -148.1 and $-161.0 \mathrm{ppm}$ for the tfbb ligand indicate that it undergoes exchange processes averaging the up and down and the left and right semispaces, as well. In this respect it should be mentioned that at $190 \mathrm{~K}$ only a slight broadening of these signals is observed pointing out that the exchange process(es) are rapid even at $190 \mathrm{~K}$. Interestingly the ${ }^{1} \mathrm{H}$ signal of the $\mathrm{NH}$ moiety is observed at $8.21 \mathrm{ppm}, 1.8 \mathrm{ppm}$ downfield shifted with respect to $\operatorname{IrCl}(\mathrm{HNP})_{2}(\mathrm{tfbb})$ (2), suggesting that the $\mathrm{NH} \cdots \mathrm{O}$ hydrogen bond present in the solid state structure is maintained in solution. Furthermore, the IR spectra of $\operatorname{IrCl}(\mathrm{HNP})_{2}(\mathrm{tfbb})(2)$ and $\operatorname{Ir}\left\{\mathrm{PO}(\mathrm{OMe})_{2}\right\}(\mathrm{HNP})_{2}(\mathrm{tfbb})$ (4) in $\mathrm{CHCl}_{3}$ exhibit two $\mathrm{N}-\mathrm{H}$ stretching bands at 3679 and 3406 $\mathrm{cm}^{-1}$ and at 3690 and $3316 \mathrm{~cm}^{-1}$, respectively, suggesting that in both compounds the two HNP are non-equivalent and, most importantly, that the $90 \mathrm{~cm}^{-1}$ difference between the band at 3406 (2) and that at $3316 \mathrm{~cm}^{-1}$ (4) should be the consequence of the intramolecular $\mathrm{NH} \cdots \mathrm{O}$ hydrogen bond present in 4 . As a confirmation, the structure of $\mathbf{4}$ was optimized at the DFTB3LYP level ${ }^{\S}$ (see ESI-Figure S7 and Table S5) and the calculated wavenumbers of the $\mathrm{N}-\mathrm{H}$ stretching bands for $\operatorname{IrCl}(\mathrm{HNP})_{2}(\mathrm{tfbb})(2)$ and $\operatorname{Ir}\left\{\mathrm{PO}(\mathrm{OMe})_{2}\right\}(\mathrm{HNP})_{2}(\mathrm{tfbb})(4)$ are 3551, $3472 \mathrm{~cm}^{-1}(2)$ and 3505, $3289(\mathrm{NH} \cdots \mathrm{O}) \mathrm{cm}^{-1}(4)$.

Mechanism of the formation of $\operatorname{Ir}\left\{\mathrm{PO}(\mathrm{OMe})_{2}\right\}(\mathrm{HNP})_{2}(\mathrm{tfbb})(4)$. In order to elucidate the pathway leading to $\operatorname{Ir}\left\{\mathrm{PO}(\mathrm{OMe})_{2}\right\}(\mathrm{HNP})_{2}(\mathrm{tfbb})$ (4) the course of the reaction between $\operatorname{IrCl}(\mathrm{HNP})_{2}(\mathrm{tfbb})$ (2) and trimethyl phosphite was monitored by ${ }^{1} \mathrm{H}$ and ${ }^{31} \mathrm{P}$ NMR spectroscopy. As soon as trimethyl phosphite is added to a $\mathrm{CDCl}_{3}$ solution of $\operatorname{IrCl}(\mathrm{HNP})_{2}(\mathrm{tfbb}) \quad$ (2) at $298 \mathrm{~K}$, the formation of $\left[\operatorname{Ir}(\mathrm{HNP})_{2}\left\{\mathrm{P}(\mathrm{OMe})_{3}\right\}(\mathrm{tfbb})\right]^{+}\left(5^{+}\right)$is observed. Due to its lability, [5] Cl could not be isolated and it has been characterised in solution at $260 \mathrm{~K}$. Its ${ }^{31} \mathrm{P}$ NMR spectrum shows two resonances at $76.8\left(\mathrm{P}(\mathrm{OMe})_{3}, 1 \mathrm{P}\right)$ and $12.6 \mathrm{ppm}\left(\mathrm{HNP}\right.$, doublet, ${ }^{2} \mathrm{~J}_{\mathrm{PP}}=30.0$ $\mathrm{Hz}, 2 \mathrm{P}$ ) in agreement with the presence of a trimethyl phosphite and two HNP ligands that coordinate the metal centre. Also a doublet at $3.76 \mathrm{ppm}\left(9 \mathrm{H},{ }^{3} \mathrm{~J}_{\mathrm{HP}}=11.1 \mathrm{~Hz}\right)$ for the methyls of the coordinated $\mathrm{P}(\mathrm{OMe})_{3}$ is observed in the ${ }^{1} \mathrm{H}$ NMR spectrum. The ${ }^{19} \mathrm{~F}$ NMR spectrum shows two signals at -146.2 and $-158.8 \mathrm{ppm}$ and the ${ }^{1} \mathrm{H}$ NMR spectrum shows signals at $2.78\left(\mathrm{C}^{\mathrm{sp2}} \mathrm{H}, 4 \mathrm{H}\right)$ and $4.02 \mathrm{ppm}\left(\mathrm{C}^{\mathrm{sp} 3} \mathrm{H}, 2 \mathrm{H}\right)$ for the coordinated tfbb, which reasonably undergo exchange process(es) averaging the up and down and the left and right semispaces.

${ }_{5}^{5}$ Selected experimental and calculated NMR data $\left(\mathrm{CDCl}_{3}, 298 \mathrm{~K}\right)$ for $4: \delta_{\mathrm{H} \text { exp }}\left(\delta_{\mathrm{H} \text { calc }}\right)=$ $8.21(7.94, \mathrm{NH}), 4.19\left(4.18, \mathrm{C}^{\mathrm{sp} 3} \mathrm{H}^{\mathrm{tfbb}}, 2 \mathrm{H}\right.$ av. $), 3.58\left(3.81, \mathrm{POCH}_{3}\right), 2.49\left(2.83, \mathrm{C}^{\mathrm{sp} 2} \mathrm{H}^{\mathrm{tbb}}, 4 \mathrm{H}\right.$ av.), $2.13\left(1.77, \mathrm{CH}_{3}{ }^{\text {tol }}\right) ; \delta_{\text {Fexp }}\left(\delta_{\text {F calc }}\right)=-148.1(-147.2,2 \mathrm{~F} \mathrm{av}),.-161.0(-161.9,2 \mathrm{~F}$ av. $)$; $\delta_{\text {exp }}\left(\delta_{\text {palc }}\right)=43.8\left(45.6, \mathrm{PO}(\mathrm{OMe})_{2}\right), 14.0(15.6, \mathrm{SiNP})$.

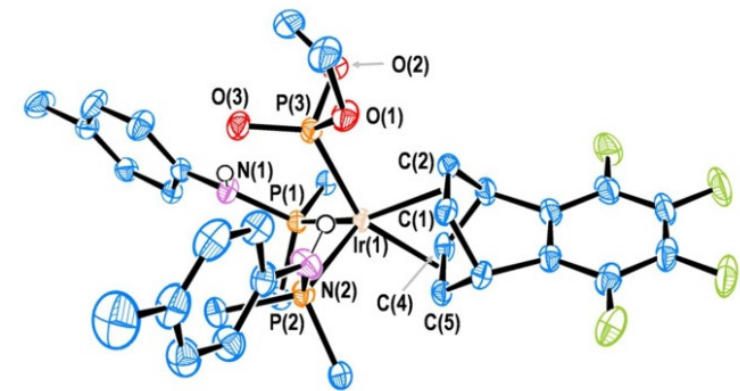

(A)

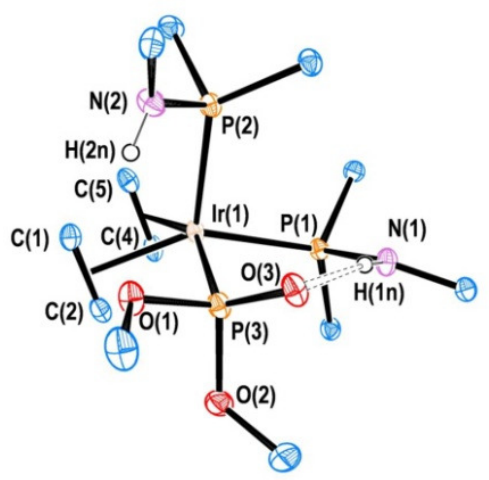

(B)

Figure 4. ORTEP view of $\operatorname{Ir}\left\{\mathrm{PO}(\mathrm{OMe})_{2}\right\}(\mathrm{SiNP})(\mathrm{tfbb})(4)$. Ellipsoids are at the $50 \%$ of probability. Only ipso carbons are shown and hydrogen atoms, except those of the $\mathrm{NH}$ groups, are omitted for clarity. (B) View of the coordination polyhedron and of the intramolecular $\mathrm{N}(1)-\mathrm{H}(1) \cdots \mathrm{O}(3)$ hydrogen bond. Selected interatomic distances and angles are in order: $\mathrm{N}(1)-\mathrm{H}(1 \mathrm{n}) 0.89(3), \mathrm{N}(1) \cdots \mathrm{O}(3) 2.813(3), \mathrm{H}(1 \mathrm{n}) \cdots \mathrm{O}(3) 1.94(3)$ $\AA, \mathrm{N}(1)-\mathrm{H}(1 \mathrm{n})-\mathrm{O}(3)$ 166(3)․․

Table 3. Selected bond lengths $(\AA)$ and angles $\left({ }^{\circ}\right)$ of $\operatorname{Ir}\left\{\mathrm{PO}(\mathrm{OMe})_{2}\right\}(\mathrm{SiNP})(\mathrm{tfbb})(4) .{ }^{*}$

$\begin{array}{llll}\operatorname{Ir}(1)-\mathrm{C}(1) & 2.131(3) & \mathrm{O}(2)-\mathrm{P}(3) & 1.631(2) \\ \operatorname{Ir}(1)-\mathrm{C}(2) & 2.150(3) & \mathrm{O}(3)-\mathrm{P}(3) & 1.496(2) \\ \operatorname{Ir}(1)-\mathrm{ct}[1-2] & 2.0172(4) & \mathrm{P}(1)-\operatorname{Ir}(1)-\mathrm{P}(2) & 99.25(3) \\ \operatorname{Ir}(1)-\mathrm{C}(4) & 2.315(3) & \mathrm{P}(1)-\operatorname{Ir}(1)-\mathrm{P}(3) & 91.78(3) \\ \operatorname{Ir}(1)-\mathrm{C}(5) & 2.300(3) & \mathrm{P}(2)-\operatorname{Ir}(1)-\mathrm{P}(3) & 93.93(3) \\ \operatorname{Ir}(1)-\mathrm{ct}[4-5] & 2.2033(5) & \mathrm{ct}[1-2]-\operatorname{Ir}(1)-\mathrm{P}(1) & 144.481(19) \\ \mathrm{C}(1)-\mathrm{C}(2) & 1.434(4) & \mathrm{ct}[4-5]-\operatorname{Ir}(1)-\mathrm{P}(1) & 99.47(2) \\ \mathrm{C}(4)-\mathrm{C}(5) & 1.374(4) & \mathrm{ct}[1-2]-\operatorname{Ir}(1)-\mathrm{P}(2) & 115.98(3) \\ \operatorname{Ir}(1)-\mathrm{P}(1) & 2.3196(8) & \mathrm{ct}[4-5]-\operatorname{Ir}(1)-\mathrm{P}(2) & 108.87(2) \\ \operatorname{Ir}(1)-\mathrm{P}(2) & 2.3599(9) & \mathrm{ct}[1-2]-\operatorname{Ir}(1)-\mathrm{P}(3) & 90.21(2) \\ \operatorname{Ir}(1)-\mathrm{P}(3) & 2.2788(9) & \mathrm{ct}[4-5]-\operatorname{Ir}(1)-\mathrm{P}(3) & 152.37(2) \\ \mathrm{O}(1)-\mathrm{P}(3) & 1.622(2) & \mathrm{ct}[1-2]-\operatorname{Ir}(1)-\mathrm{ct}[4-5] & 66.129(8)\end{array}$

* $\operatorname{ct}[\mathrm{X}-\mathrm{Y}]$ : centroid of the $\mathrm{C}(\mathrm{X})-\mathrm{C}(\mathrm{Y})$ bond.

Finally the ${ }^{1} \mathrm{H}$ signal for $\mathrm{NH}$ is observed at $6.57 \mathrm{ppm}$ at $260 \mathrm{~K}$ (6.61 ppm at $298 \mathrm{~K}$ ). 
Scheme 8
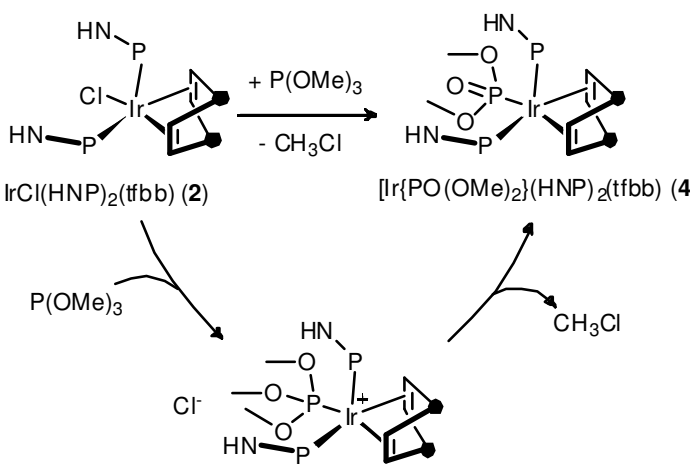

$\left[\operatorname{lr}(\mathrm{HNP})_{2}\left\{\mathrm{P}(\mathrm{OMe})_{3}\right\}(\mathrm{tbb})\right] \mathrm{Cl}([5] \mathrm{Cl})$

The compound $\left[\operatorname{Ir}(\mathrm{HNP})_{2}\left\{\mathrm{P}(\mathrm{OMe})_{3}\right\}(\mathrm{tfbb})\right] \mathrm{Cl}([5] \mathrm{Cl})$ directly and cleanly converts into $\operatorname{Ir}\left\{\mathrm{PO}(\mathrm{OMe})_{2}\right\}(\mathrm{HNP})_{2}(\mathrm{tfbb})(4)$ (Scheme 8, $100 \%$ conversion after $2 \mathrm{~h}$ at room temperature, Figure 5$)$. In addition, as long as 4 forms, an increasing ${ }^{1} \mathrm{H}$ signal at 3.02 $\mathrm{ppm}^{16}\left(\delta_{\mathrm{C}}=26.0 \mathrm{ppm}\right)$ is observed indicating that methyl chloride is also produced in the course of the reaction. On these bases, the reaction $2+\mathrm{P}(\mathrm{OMe})_{3} \rightarrow 4+\mathrm{CH}_{3} \mathrm{Cl}$ follows the two-step Arbuzov mechanism: ${ }^{15 e, 17}$ (i) formation of the trialkyl phosphite-metal complex and (ii) dealkylation of coordinated trialkyl phosphite yielding the metal phosphonate complex and the corresponding alkyl halide.

At variance with $\left[\operatorname{Ir}(\mathrm{HNP})_{2}\left\{\mathrm{P}(\mathrm{OMe})_{3}\right\}(\mathrm{tfbb})\right] \mathrm{Cl}([5] \mathrm{Cl})$, it is worth mentioning that $\left[\mathrm{Ir}(\mathrm{SiNP})\left\{\mathrm{P}(\mathrm{OMe})_{3}\right\}(\mathrm{tfbb})\right] \mathrm{Cl}([3] \mathrm{Cl})$ remains unchanged in $\mathrm{CH}_{2} \mathrm{Cl}_{2}$ or $\mathrm{CHCl}_{3}$ solutions after 7 days at room temperature. In order to elucidate the factors determining such a surprisingly different chemical behaviour of $[3] \mathrm{Cl}$ and

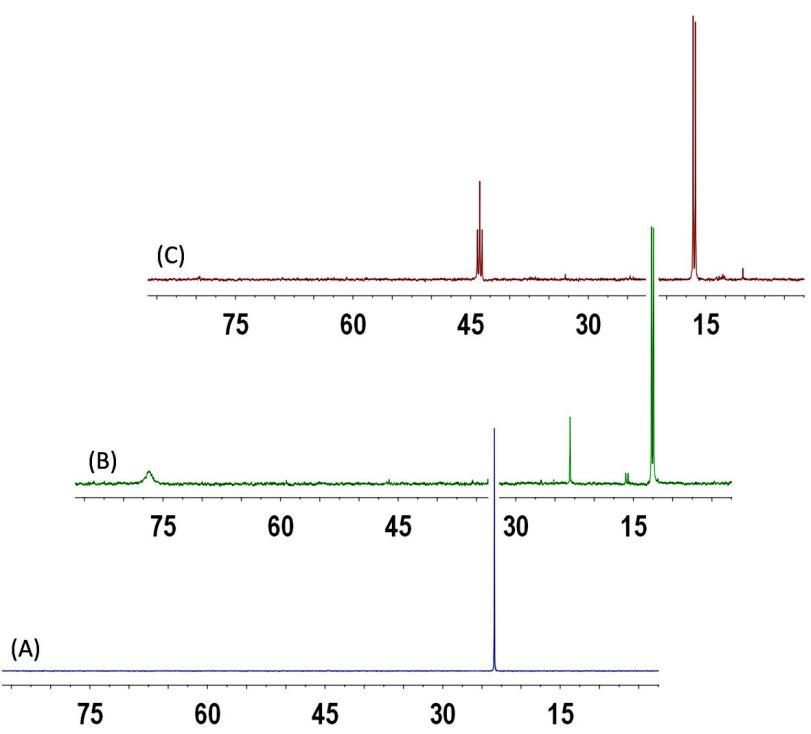

Figure 5. Consecutive ${ }^{31} \mathrm{P}\left\{{ }^{1} \mathrm{H}\right\} \mathrm{NMR}$ spectra $\left(\mathrm{CDCl}_{3}\right)$ of $(\mathrm{A}) \operatorname{IrCl}(\mathrm{HNP})_{2}(\mathrm{tfbb})(\mathbf{2})$ at $298 \mathrm{~K}$; (B) $\left[\operatorname{Ir}(\mathrm{HNP})_{2}\left\{\mathrm{P}(\mathrm{OMe})_{3}\right\}(\mathrm{tfbb})\right] \mathrm{Cl}([5] \mathrm{Cl})$ prepared in situ by adding $\mathrm{P}(\mathrm{OMe})_{3}$ to 2 at $260 \mathrm{~K}$ (1:1 molar ratio); and (C) $\operatorname{Ir}\left\{\mathrm{PO}(\mathrm{OMe})_{2}\right\}(\mathrm{HNP})_{2}(\mathrm{tfbb})(4)$ finally obtained from [5] Cl after $2 \mathrm{~h}$ at $298 \mathrm{~K}$.

[5]Cl, a DFT-B3LYP study was undertaken and the energy profile for the observed reaction $5^{+}+\mathrm{Cl}^{-} \rightarrow 4+\mathrm{CH}_{3} \mathrm{Cl}$ and for the putative one $\mathbf{3}^{+}+\mathrm{Cl}^{-} \rightarrow 3-\mathrm{Me}+\mathrm{CH}_{3} \mathrm{Cl}$ (3-Me $=$ $\left.\operatorname{Ir}\left\{\mathrm{PO}(\mathrm{OMe})_{2}\right\}(\mathrm{SiNP})(\mathrm{tfbb})\right)$ were calculated (Figure 6).

An $\mathrm{S}_{\mathrm{N}}$ 2-type transition state was found for both reactions resulting from the attack of chloride anion at one of the methyl groups of the coordinated trimethyl phosphite in $3^{+}$or $5^{+}$. Accordingly the $\mathrm{CH}_{3}$ moiety undergoing the nucleophilic attack is almost planar and the calculated interatomic

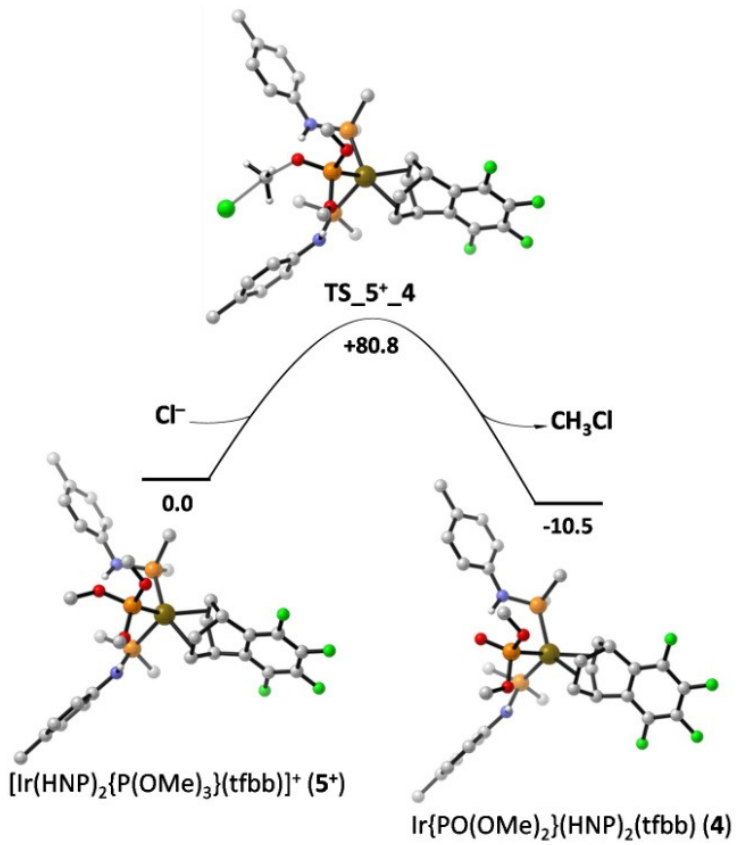

(A)

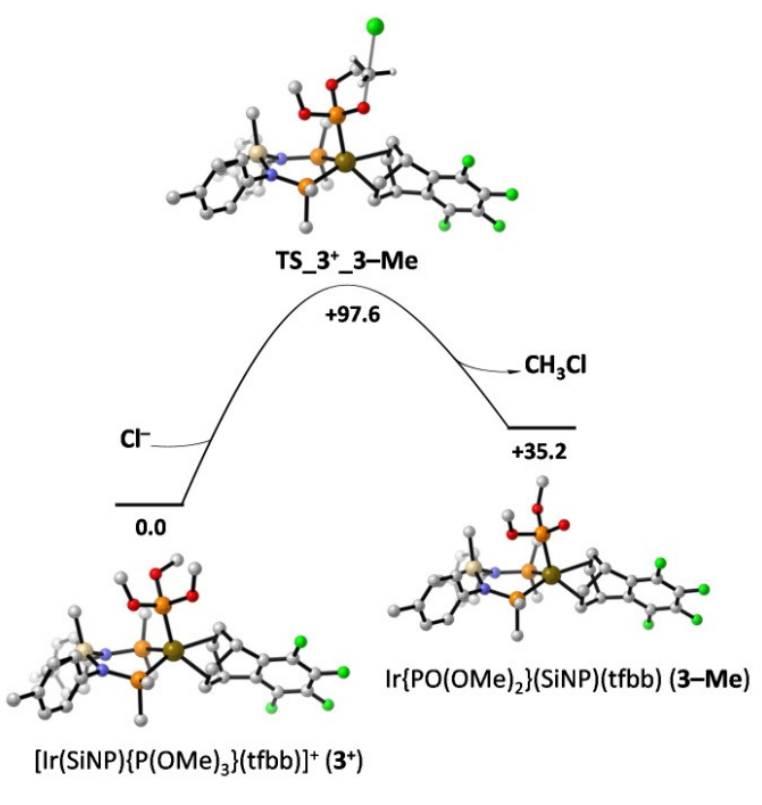

(B)

Figure 6. Energy profile $\left(\mathrm{kJ} \cdot \mathrm{mol}^{-1}\right)$ for the reactions $(\mathrm{A}) \mathbf{5}^{+}+\mathrm{Cl}^{-} \rightarrow \mathbf{4}+\mathrm{CH}_{3} \mathrm{Cl}$ and $(\mathrm{B}) \mathbf{3}^{+}+\mathrm{Cl}^{-} \rightarrow \mathbf{3}-\mathrm{Me}+\mathrm{CH}_{3} \mathrm{Cl}\left(298 \mathrm{~K}, \mathrm{CH}_{2} \mathrm{Cl}_{2}\right) \cdot \mathrm{Most}$ hydrogen atoms are omitted and only ipso carbon atoms are shown for clarity. 


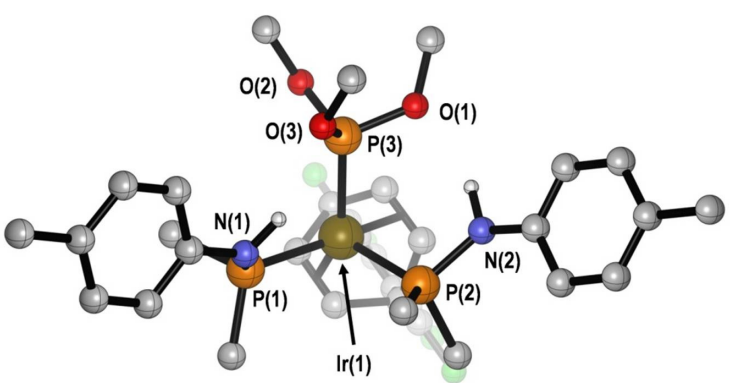

$\left[\operatorname{lr}(\mathrm{HNP})_{2}\left\{\mathrm{P}(\mathrm{OMe})_{3}\right\}(\mathrm{tfbb})\right]^{+}\left(5^{+}\right)$

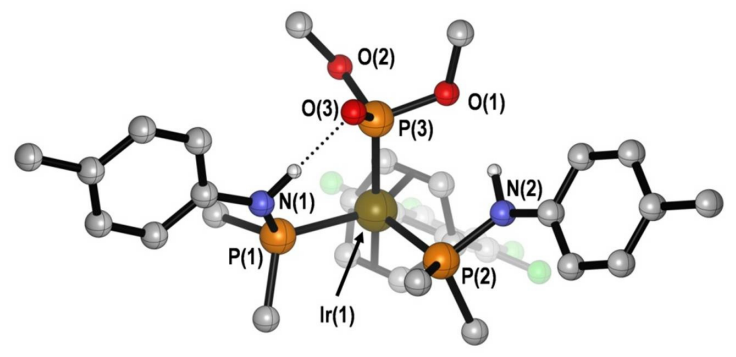

$\operatorname{Ir}\left\{\mathrm{PO}(\mathrm{OMe})_{2}\right\}(\mathrm{HNP})_{2}(\mathrm{tfbb})(4)$

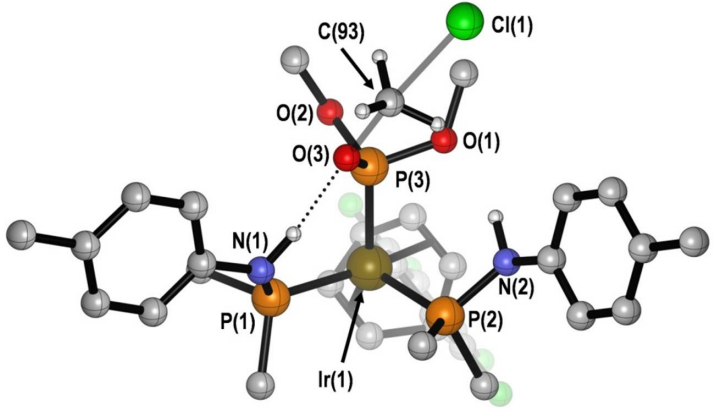

TS_5+4

\begin{tabular}{|c|c|c|c|c|}
\hline & \multicolumn{3}{|c|}{ Selected bond lengths (Å) } & \multirow[b]{2}{*}{4 (x-ray) } \\
\hline & $5^{+}$ & TS_5 $5^{+} 4$ & 4 & \\
\hline$N(1)-O(3)$ & 3.092 & 2.908 & 2.829 & $2.813(3)$ \\
\hline$N(2)-O(1)$ & 3.081 & 3.021 & 3.029 & $3.108(5)$ \\
\hline$P(3)-O(1)$ & 1.651 & 1.657 & 1.669 & $1.622(2)$ \\
\hline$P(3)-O(2)$ & 1.637 & 1.654 & 1.667 & $1.631(2)$ \\
\hline$P(3)-O(3)$ & 1.647 & 1.581 & 1.522 & $1.496(2)$ \\
\hline$O(3)-C(93)$ & 1.443 & 1.789 & - & - \\
\hline $\operatorname{lr}(1)-P(3)$ & 2.305 & 2.336 & 2.313 & $2.2788(9)$ \\
\hline $\mathrm{C}(93)-\mathrm{Cl}(1)$ & - & 2.516 & - & - \\
\hline
\end{tabular}

Figure 7. View of the DFT-B3LYP calculated structure of $\left[\operatorname{Ir}(\mathrm{HNP})_{2}\left\{\mathrm{P}(\mathrm{OMe})_{3}\right\}(\mathrm{tfbb})\right]^{+}\left(5^{+}\right), \operatorname{Ir}\left\{\mathrm{PO}(\mathrm{OMe})_{2}\right\}(\mathrm{HNP})_{2}(\mathrm{tfbb})(4)$, and TS_5 $5^{+}{ }^{4}$ along with selected bond lengths $(\AA)^{2}$.

distances $C \cdots O$ (TS_5 ${ }^{+}$4, $1.789 \AA \AA^{\prime}$ TS_3 ${ }^{+}$3-Me, $1.785 \AA$ ) and C...Cl (TS_5 ${ }^{+}$4, $2.516 \AA \AA$; TS_3 $^{+}{ }^{+}$3-Me, $2.512 \AA$ ) are longer than the calculated $\mathrm{C}-\mathrm{O}\left(\mathbf{3}^{+}, 1.440 \AA \mathbf{5}^{+}, 1.443 \AA\right.$ ) and $\mathrm{C}-\mathrm{Cl}(1.813 \AA)$ bond lengths of the trimethylphosphite cations $3^{+}$or $5^{+}$and methyl chloride, respectively (Figure 7). Also the moiety $\mathrm{Cl} \cdots \mathrm{C} \cdots \mathrm{O}$ is almost linear $\left(\mathrm{TS}_{-} \mathbf{5}^{+} \mathbf{4}_{\mathbf{4}}, \mathbf{1 7 1 . 0 ^ { \circ }}\right.$; TS_3 $\mathbf{3}_{-}^{+} \mathbf{3}-\mathrm{Me}$, $179.0^{\circ}$ ) in agreement with the rear attack typical of the $S_{N} 2$ reaction. Nevertheless, despite the similar geometric features of the $\mathrm{O} \cdots \mathrm{CH}_{3} \cdots \mathrm{Cl}$ moiety in TS_5 ${ }_{-}^{+} 4$ and TS_3 ${ }^{+}{ }_{3}$-Me significantly different activation barriers were calculated (Figure 6), pointing at that the methyl abstraction should be almost three orders of magnitude faster in the HNP derivative than in the SiNP one. Further, the formation of the phosphonato derivative 4 was found exoergonic ( $\Delta G=-10.5$ $\mathrm{kJ} \cdot \mathrm{mol}^{-1}$ ) while the formation of 3-Me was found to be endoergonic $\left(\Delta G=+35.2 \mathrm{~kJ} \cdot \mathrm{mol}^{-1}\right)$, thus indicating that the formation of 3-Me should be prevented by unfavourable thermodynamics, as well.

An overview of the calculated structures $5^{+}$, TS $_{-} \mathbf{5}^{+} \mathbf{4}$ and 4 reveals that an intramolecular $\mathrm{NH} \cdots \mathrm{OP}$ hydrogen bond is present not only in $\mathbf{4}$ but also in $\mathbf{T S} \mathbf{5}^{+} \mathbf{4}$. Indeed, as expected, the optimised structure of $\mathbf{4}$ displays a short $\mathrm{N} \cdots \mathrm{O}$ contact $(\mathrm{N}(1) \cdots \mathrm{O}(3), 2.829 \AA$, Figure 7) which matches the presence of the intramolecular $\mathrm{N}-\mathrm{H} \cdots \mathrm{O}=\mathrm{P}$ hydrogen bond observed in the solid state structure and in solution. Also, the transition state TS_5 ${ }^{+}$4 features a short contact $\mathrm{N} \cdots \mathrm{O}(\mathrm{N}(1) \cdots \mathrm{O}(3), 2.908 \AA$, Figure 7) suggesting that, similarly to 4 , there also exists an $\mathrm{NH} \cdots \mathrm{O}$ hydrogen bond. On the other hand, based on the calculated $\mathrm{N} \cdots \mathrm{O}$ interatomic distance (3.092 $\AA$, Figure 7), the presence of $\mathrm{NH} \cdots \mathrm{O}$ hydrogen bonds in $5^{+}$should be ruled out.
In this respect, as a confirmation it should be reminded that the $\mathrm{NH}^{1} \mathrm{H}$-signal of $\mathbf{5}^{+}(6.61 \mathrm{ppm}$ at $298 \mathrm{~K})$ is only slightly shifted with respect to that of $2(6.44 \mathrm{ppm})$, whereas the $\mathrm{NH}$ ${ }^{1} \mathrm{H}$ signal of 4 is observed significantly downfield shifted (8.21 ppm).

On these bases, both the lower activation barrier and the favourable thermodynamics for the reaction $5^{+}+\mathrm{Cl}^{-} \rightarrow \mathbf{4}+\mathrm{CH}_{3} \mathrm{Cl}$ with respect to the putative reaction $3^{+}+\mathrm{Cl}^{-} \rightarrow 3-\mathrm{Me}+\mathrm{CH}_{3} \mathrm{Cl}$ should rely on the stabilization provided by the intramolecular $\mathrm{NH} \cdots \mathrm{OP}$ bond both to the transition state $\mathbf{T S} \mathbf{5}^{+}{ }_{-} \mathbf{4}$ and to the final phosphonato complex 4.

\section{CONCLUSIONS}

The pentacoordinated iridium(I) complexes $\operatorname{IrCl}(\mathrm{SiNP})(\mathrm{tfbb})(\mathbf{1})$ and $\operatorname{IrCl}(\mathrm{HNP})_{2}(\mathrm{tfbb})$ (2) display distorted square pyramidal geometries in which the configuration at the metal centre depends on the nature of the amino-phosphane ligand, namely SPY-5-23 for the HNP derivative and SPY-5-13 for the SiNP one. Both complexes are fluxional in solution presenting rapid exchange of the up and down and the left and right semispaces at tfbb $(\mathbf{1}, \mathbf{2})$ and at $\operatorname{SiNP}(\mathbf{1})$. In addition, the rapid exchange of the two HNP ligands is operative in $\mathbf{2}$.

The reactions of $\mathbf{1}$ and of $\mathbf{2}$ with trimethyl phosphite afford the cations $\quad\left[\operatorname{Ir}(\mathrm{SiNP})\left\{\mathrm{P}(\mathrm{OMe})_{3}\right\}(\mathrm{tfbb})\right]^{+} \quad\left(\mathbf{3}^{+}\right) \quad$ and $\left[\operatorname{Ir}(\mathrm{HNP})_{2}\left\{\mathrm{P}(\mathrm{OMe})_{3}\right\}(\mathrm{tfbb})\right]^{+}\left(5^{+}\right)$, respectively, resulting from the $\mathrm{Cl}^{-} / \mathrm{P}(\mathrm{OMe})_{3}$ substitution. Their structure parallels that of the corresponding starting material. Indeed a distorted square pyramidal coordination polyhedron is observed for both $\mathbf{3}^{+}$ (SPY-5-13) and $\mathbf{5}^{+}$(SPY-5-23). Most relevant, [3]Cl is stable both 
in the solid state and in solution, while $[5] \mathrm{Cl}$ is labile in solution and rapidly transforms into $\operatorname{Ir}\left\{\mathrm{PO}(\mathrm{OMe})_{2}\right\}(\mathrm{HNP})_{2}(\mathrm{tfbb})$ (4) releasing methyl chloride. Similar to $\mathbf{2}$, the phosphonato derivative 4 displays a slightly distorted square pyramidal coordination polyhedron with a SPY-5-23 configuration at the metal centre. An $\mathrm{NH} \cdots \mathrm{O}$ intermolecular hydrogen bond between one $\mathrm{NH}$ moiety and the $\mathrm{P}=\mathrm{O}$ group has been observed in the solid state and is maintained in solution.

The formation of $\mathbf{4}$ from $\mathbf{5}^{+}$takes place via an $\mathrm{S}_{\mathrm{N}} 2$ type reaction in which the chloride anion attacks at one methyl group of the coordinated trimethyl phosphito ligand in $\mathbf{5}^{+}$thus affording methyl chloride and the phosphonato complex 4 . The ability of HNP to form intramolecular $\mathrm{NH} \cdots \mathrm{O}$ hydrogen bond is responsible for the different chemical behaviour of $[3] \mathrm{Cl}$ and [5] Cl in solution. In fact, this interaction makes thermodynamically favourable the formation of $\mathbf{4}$, whereas the formation of the putative $\mathbf{3}-\mathbf{M e}$ is endoergonic. Further, the observed reaction $5^{+}+\mathrm{Cl}^{-} \rightarrow \mathbf{4}+\mathrm{CH}_{3} \mathrm{Cl}$ was calculated to be almost three orders of magnitude faster than the putative reaction $3^{+}+\mathrm{Cl}^{-} \rightarrow 3-\mathrm{Me}+\mathrm{CH}_{3} \mathrm{Cl}$ as a consequence of the

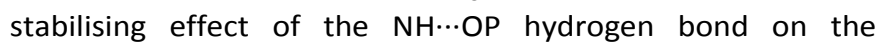
transition state, as well.

\section{EXPERIMENTAL SECTION}

All the operations were carried out using standard schlenktube techniques or in a Braun glove-box under an atmosphere of prepurified argon. The solvent were dried and purified according to standard procedures. $\mathrm{P}(\mathrm{OMe})_{3}$ (Aldrich) was commercially available and was used as received if not otherwise stated. The compounds $\operatorname{IrCl}(\mathrm{tfbb})_{2}{ }^{18} \mathrm{SiNP}^{10}$ and $H N P^{10}$ were prepared as previously described in the literature. NMR spectra were measured with Bruker spectrometers (AV300, AV400) and are referred to $\mathrm{SiMe}_{4}\left({ }^{1} \mathrm{H},{ }^{13} \mathrm{C}\right), \mathrm{H}_{3} \mathrm{PO}_{4}\left({ }^{31} \mathrm{P}\right)$ and $\mathrm{CFCl}_{3}\left({ }^{19} \mathrm{~F}\right)$. The ${ }^{13} \mathrm{C}$ NMR signals were assigned according to the ${ }^{1} \mathrm{H}-{ }^{13} \mathrm{C}$ HSQC (non-quaternary carbon atoms) and ${ }^{1} \mathrm{H}-{ }^{13} \mathrm{C}$ $\mathrm{HMBC}$ spectra (quaternary carbon atoms). For clarity the ${ }^{13} \mathrm{C}$ chemical shift $\left(\delta_{\mathrm{C}}\right)$ of non-quaternary carbon atoms are given along with the ${ }^{1} \mathrm{H}$ NMR data. The ${ }^{13} \mathrm{C}$ chemical shift $\left(\delta_{\mathrm{C}}\right)$ of quaternary carbon atoms which could be assigned reliably are given in the subsection " ${ }^{13} \mathrm{C} N M R^{\prime}$ following the ${ }^{1} \mathrm{H}$ NMR data. Infrared spectra were recorded on a Thermo Nicolet Avatar $360 \mathrm{FT}-\mathrm{IT}$ spectrometer on $\mathrm{CHCl}_{3}$ solutions using $\mathrm{KBr}$ windows (1 $\mathrm{mm}$ path). Elemental analyses were performed by using a Perkin-Elmer 2400 microanalyzer.

Synthesis of $\operatorname{IrCl}(\operatorname{SiNP})(\mathbf{t f b b})$ (1). A suspension of SiNP (466 mg, $\left.0,729 \mathrm{mmol}, 638.81 \mathrm{~g} \cdot \mathrm{mol}^{-1}\right)$ in $\mathrm{CH}_{2} \mathrm{Cl}_{2}(5 \mathrm{~mL})$ was added with $\mathrm{IrCl}(\mathrm{tfbb})_{2}\left(495 \mathrm{mg}, 0.728 \mathrm{mmol}, 680.01 \mathrm{~g} \cdot \mathrm{mol}^{-1}\right)$. The mixture was stirred for $1 \mathrm{~h}$ and the resulting solid was filtered off, dried in vacuo and identified as $\operatorname{IrCl}(\operatorname{SiNP})(\mathrm{tfbb})(\mathbf{1})(588 \mathrm{mg}, 74 \%$ yield). Found: $\mathrm{C}, 57.22 ; \mathrm{H}, 4.28 ; \mathrm{N}, 2.66$. Calcd for $\mathrm{C}_{52} \mathrm{H}_{46} \mathrm{ClF}_{4} \mathrm{IrN}_{2} \mathrm{P}_{2} \mathrm{Si}$ (1092.65): C, 57.16; $\mathrm{H}, 4.24 ; \mathrm{N}, 2.56 .{ }^{1} \mathrm{H} N M R$ $\left(\mathrm{CD}_{2} \mathrm{Cl}_{2}, 298 \mathrm{~K}\right): \delta=7.17-7.72(2 \mathrm{OH}, \mathrm{PPh}), 6.75\left(\mathrm{~d},{ }^{3} J_{\mathrm{HH}}=8.2 \mathrm{~Hz}\right.$, $\left.4 \mathrm{H}, \mathrm{C}^{2} \mathrm{H}^{\text {tol }}, \delta_{\mathrm{C}}=128.7\right), 6.64\left(\mathrm{~d}, 4 \mathrm{H},{ }^{3} \mathrm{~J}_{\mathrm{HH}}=8.2 \mathrm{~Hz}, \mathrm{C}^{3} \mathrm{H}^{\text {tol }}, \delta_{\mathrm{C}}=\right.$ 131.4), $4.78\left(\mathrm{~m}, 2 \mathrm{H}, \mathrm{C}^{\mathrm{sp} 3} \mathrm{H}^{\mathrm{tfbb}}, \delta_{\mathrm{C}}=35.2 \mathrm{ppm}\right), 2.39(\mathrm{~m}, 4 \mathrm{H}$, $\left.\mathrm{C}^{\mathrm{sp} 2} \mathrm{H}^{\mathrm{tfbb}}, \delta_{\mathrm{C}}=39.9 \mathrm{ppm}\right), 2.16\left(\mathrm{~s}, 6 \mathrm{H}, \mathrm{CH}_{3}{ }^{\mathrm{tol}}, \delta_{\mathrm{C}}=18.5 \mathrm{ppm}\right)$, $0.33\left(\mathrm{br}, 6 \mathrm{H}, \mathrm{SiCH}_{3}\right) .{ }^{19} \mathrm{~F} \mathrm{NMR}\left(\mathrm{CD}_{2} \mathrm{Cl}_{2}, 298 \mathrm{~K}\right): \delta=-148.0(\mathrm{~m}, 2 \mathrm{~F}$, tfbb), -161.3 (m, 2F, tfbb). ${ }^{31} \mathrm{P}\left\{{ }^{1} \mathrm{H}\right\} \operatorname{NMR}\left(\mathrm{CD}_{2} \mathrm{Cl}_{2}, 298 \mathrm{~K}\right): \delta=$ 47.2 (s).

Synthesis of $\operatorname{IrCl}(\mathrm{HNP})_{\mathbf{2}}$ (tfbb) (2). A suspension of $\operatorname{IrCl}(\mathrm{tfbb})_{2}$ (111 mg, $0.163 \mathrm{mmol}, 680.01 \mathrm{~g} \cdot \mathrm{mol}^{-1}$ ) in $\mathrm{CH}_{2} \mathrm{Cl}_{2}(5 \mathrm{~mL}$ ) was added with HNP (96.8 $\left.\mathrm{mg}, 0.332 \mathrm{mmol}, 291.33 \mathrm{~g} \cdot \mathrm{mol}^{-1}\right)$. The resulting yellow-orange solution was stirred for $6 \mathrm{~h}$ and finally evaporated up to dryness affording a yellow residue. The solid was extracted with diethylether $(3 \mathrm{~mL})$ and the extract was added with hexane $(4 \mathrm{~mL})$ affording a yellow-orange solid identified as $\operatorname{IrCl}(\mathrm{HNP})_{2}$ (tfbb) $(2,122 \mathrm{mg}, 72 \%$ yield). Found: $\mathrm{C}$, 58.01; $\mathrm{H}, 4.05 ; \mathrm{N}, 2.58$. Calcd for $\mathrm{C}_{50} \mathrm{H}_{42} \mathrm{ClF}_{4} \mathrm{IrN}_{2} \mathrm{P}_{2}$ (1036.51): $\mathrm{C}$, 57.94; $\mathrm{H}, 4.08 ; \mathrm{N}, 2.70 .{ }^{1} \mathrm{H}$ NMR $\left(\mathrm{CDCl}_{3}, 298 \mathrm{~K}\right): \delta=7.43(\mathrm{~m}, 4 \mathrm{H}$, $o-\mathrm{PPh}^{1}, \delta_{\mathrm{C}}=131.8$ ), 7.32 (total $6 \mathrm{H}: 4 \mathrm{H}, o-\mathrm{PPh}^{2}, \delta_{\mathrm{C}}=131.2 ; 2 \mathrm{H}$, $p-\mathrm{PPh}^{1}, \delta_{\mathrm{C}}=129.8$ ), 7.23 (total $10 \mathrm{H}: 2 \mathrm{H}, p-\mathrm{PPh}^{2}, \delta_{\mathrm{C}}=129.7$; $\left.8 \mathrm{H}, m-\mathrm{PPh}, \delta_{\mathrm{C}}=127.92,127.87\right), 6.71\left(\mathrm{~d},{ }^{3} J_{\mathrm{HH}}=8.0 \mathrm{~Hz}, 4 \mathrm{H}\right.$, $\left.\mathrm{C}^{3} \mathrm{H}^{\text {tol }}, \delta_{\mathrm{C}}=128.9\right), 6.44(\mathrm{~m}, 2 \mathrm{H}, \mathrm{NH}), 6.25\left(\mathrm{~d},{ }^{3} \mathrm{~J}_{\mathrm{HH}}=8.0 \mathrm{~Hz}, 4 \mathrm{H}\right.$, $\left.\mathrm{C}^{2} \mathrm{H}^{\mathrm{tol}}, \delta_{\mathrm{C}}=117.8\right), 5.07\left(\mathrm{~m}, 2 \mathrm{H}, \mathrm{C}^{\mathrm{sp} 3} \mathrm{H}^{\mathrm{tfbb}}, \delta_{\mathrm{C}}=35.8\right), 2.41(\mathrm{~m}$, $\left.4 \mathrm{H}, \mathrm{C}^{\mathrm{sp2}} \mathrm{H}^{\mathrm{tfbb}}, \delta_{\mathrm{C}}=37.7\right), 2.12\left(\mathrm{~s}, 6 \mathrm{H}, \mathrm{CH}_{3}{ }^{\mathrm{tol}}, \delta_{\mathrm{C}}=20.4\right) .{ }^{13} \mathrm{C}\left\{{ }^{1} \mathrm{H}\right\}$ $\mathrm{NMR}\left(\mathrm{CDCl}_{3}, 298 \mathrm{~K}\right): \delta=129.2\left(\mathrm{C}^{4 \text { tol }}\right), 140.4\left(\mathrm{C}^{1 \text { tol }}\right) .{ }^{19} \mathrm{~F} \mathrm{NMR}$ $\left(298 \mathrm{~K}, \mathrm{CDCl}_{3}\right): \delta=-147.7(\mathrm{~m}, 2 \mathrm{~F}, \mathrm{tfbb}),-160.5(\mathrm{~m}, 2 \mathrm{~F}, \mathrm{tfbb})$. ${ }^{31} \mathrm{P}\left\{{ }^{1} \mathrm{H}\right\} \mathrm{NMR}\left(298 \mathrm{~K}, \mathrm{CDCl}_{3}\right): \delta=23.4$ (s, HNP). IR $\left(\mathrm{CHCl}_{3}, 298 \mathrm{~K}\right)$ : $3679\left(v_{\mathrm{NH}}\right), 3406\left(v_{\mathrm{NH}}\right) \mathrm{cm}^{-1}$.

Synthesis of $\left[\operatorname{Ir}(\mathrm{SiNP})\left\{\mathrm{P}(\mathrm{OMe})_{3}\right\}(\mathrm{tfbb})\right] \mathrm{Cl}([3] \mathrm{Cl})$. A solution of IrCl(tfbb)(SiNP) (190 mg, $0.174 \mathrm{mmol}, 1092.65 \mathrm{~g} \cdot \mathrm{mol}^{-1}$ ) in $\mathrm{CH}_{2} \mathrm{Cl}_{2}(5 \mathrm{~mL})$ was added with $\mathrm{P}(\mathrm{OMe})_{3}(20.5 \mu \mathrm{L}, 0.174 \mathrm{mmol}$, $124.08 \mathrm{~g} \cdot \mathrm{mol}^{-1}, 1.052 \mathrm{~g} \cdot \mathrm{mL}^{-1}$ ). After $30 \mathrm{~min}$ stirring, all volatiles were removed and the solid washed with diethylether $(2 \times 5$ $\mathrm{mL})$ and finally identified as $\left[\operatorname{Ir}(\mathrm{SiNP})\left\{\mathrm{P}(\mathrm{OMe})_{3}\right\}(\mathrm{tfbb})\right] \mathrm{Cl}([3] \mathrm{Cl}$, $165 \mathrm{mg}, 78 \%$ yield). Found: $\mathrm{C}, 54.02 ; \mathrm{H}, 4.45 ; \mathrm{N}, 2.28$. Calcd for $\mathrm{C}_{42} \mathrm{H}_{39} \mathrm{IrN} \mathrm{N}_{2} \mathrm{O}_{2} \mathrm{P}_{2} \mathrm{Si}$ (1216.73): C, 54.29; $\mathrm{H}, 4.56 ; \mathrm{N}, 2.30 .{ }^{1} \mathrm{H}$ NMR $\left(\mathrm{CDCl}_{3}, 298 \mathrm{~K}\right):^{* *} \delta=7.59$ (total $6 \mathrm{H}: 4 \mathrm{H}, o-\mathrm{PPh}, \delta_{\mathrm{C}}=134.2 ; 2 \mathrm{H}$, p-PPh, $\delta_{\mathrm{C}}=131.1$ ), $7.41-7.12$ (total $14 \mathrm{H}: 4 \mathrm{H}, o-\mathrm{PPh}, \delta_{\mathrm{C}}=$ $\left.133.8 ; 2 \mathrm{H}, p-\mathrm{PPh}, \delta_{\mathrm{C}}=130.7 ; 8 \mathrm{H}, m-\mathrm{PPh}, \delta_{\mathrm{C}}=127.4,127.5\right)$, $6.75\left(\mathrm{~d},{ }^{3} \mathrm{~J}_{\mathrm{HH}}=8.0 \mathrm{~Hz}, 2 \mathrm{H}, \mathrm{C}^{3} \mathrm{H}^{\mathrm{tol}, \mathrm{u}}, \delta_{\mathrm{C}}=130.66\right), 6.70\left(\mathrm{~d},{ }^{3} J_{\mathrm{HH}}=\right.$ $\left.8.0 \mathrm{~Hz}, 2 \mathrm{H}, \mathrm{C}^{3} \mathrm{H}^{\mathrm{tol}, \mathrm{d}}, \delta_{\mathrm{C}}=128.9\right), 6.60\left(\mathrm{~d},{ }^{3} \mathrm{~J}_{\mathrm{HH}}=8.0 \mathrm{~Hz}, 2 \mathrm{H}\right.$, $\left.\mathrm{C}^{2} \mathrm{H}^{\mathrm{tol}, \mathrm{u}}, \delta_{\mathrm{C}}=130.69\right), 6.30\left(\mathrm{~d},{ }^{3} \mathrm{~J}_{\mathrm{HH}}=8.0 \mathrm{~Hz}, 2 \mathrm{H}, \mathrm{C}^{2} \mathrm{H}^{\mathrm{tol}, \mathrm{d}}, \delta_{\mathrm{C}}=\right.$ 131.7), $4.76\left(\mathrm{br}, 2 \mathrm{H}, \mathrm{C}^{\mathrm{sp} 3} \mathrm{H}^{\mathrm{tfbb}}, \delta_{\mathrm{C}}=33.2\right), 3.88\left(\mathrm{~d},{ }^{3} J_{\mathrm{HP}}=11.0 \mathrm{~Hz}\right.$, $\left.9 \mathrm{H}, \mathrm{P}(\mathrm{OMe})_{3}, \delta_{\mathrm{C}}=55.4\right), 2.67\left(\mathrm{~m}, 4 \mathrm{H}, \mathrm{C}^{\mathrm{sp} 2} \mathrm{H}^{\mathrm{tfbb}}, \delta_{\mathrm{C}}=38.5\right), 2.16$ $\left(\mathrm{s}, 6 \mathrm{H}, \mathrm{CH}_{3}{ }^{\text {tol }}, \delta_{\mathrm{C}}=20.9\right), 0.79\left(\mathrm{~s}, 3 \mathrm{H}, \mathrm{SiCH}_{3}{ }^{\mathrm{u}}, \delta_{\mathrm{C}}=3.0\right),-0.38(\mathrm{~s}$, $\left.3 \mathrm{H}, \mathrm{SiCH}_{3}{ }^{\mathrm{d}}, \delta_{\mathrm{C}}=4.8\right) .{ }^{19} \mathrm{~F} \mathrm{NMR}\left(\mathrm{CDCl}_{3}, 298 \mathrm{~K}\right): \delta=-146.1(\mathrm{~m}, 2 \mathrm{~F}$, $\mathrm{tfbb}),-158.6(\mathrm{~m}, 2 \mathrm{~F}, \mathrm{tfbb}) .{ }^{31} \mathrm{P}\left\{{ }^{1} \mathrm{H}\right\} \mathrm{NMR}\left(\mathrm{CDCl}_{3}, 298 \mathrm{~K}\right): \delta=82.5$ $\left(\mathrm{t},{ }^{2} J_{\mathrm{PP}}=7.2 \mathrm{~Hz}, 1 \mathrm{P}, \mathrm{P}(\mathrm{OMe})_{3}\right), 39.3\left(\mathrm{~d},{ }^{2} J_{\mathrm{PP}}=7.2 \mathrm{~Hz}, 2 \mathrm{P}, \mathrm{SiNP}\right)$.

Synthesis of $\operatorname{Ir}\left\{\mathrm{PO}(\mathrm{OMe})_{2}\right\}(\mathrm{HNP})_{2}$ (tfbb) (4). $\mathrm{A} \mathrm{CH}_{2} \mathrm{Cl}_{2}(5 \mathrm{~mL})$ solution of $\operatorname{IrCl}(\mathrm{HNP})_{2}(\mathrm{tfbb})(150 \mathrm{mg}, 0.145 \mathrm{mmol}, 1036.51$ $\left.\mathrm{g} \cdot \mathrm{mol}^{-1}\right)$ was added with $\mathrm{P}(\mathrm{OMe})_{3}(17.1 \mu \mathrm{L}, 0.145 \mathrm{mmol}$, $\left.124.08 \mathrm{~g} \cdot \mathrm{mol}^{-1}, 1.052 \mathrm{~g} \cdot \mathrm{mL}^{-1}\right)$. After $3 \mathrm{~h}$ stirring all volatiles were removed in vacuo and the residue washed with hexane $(2 \times 5 \mathrm{~mL})$ affording a pale yellow solid identified as Ir $\left\{\mathrm{PO}(\mathrm{OMe})_{2}\right\}(\mathrm{HNP})_{2}$ (tfbb) $(4,137 \mathrm{mg}, 85 \%$ yield). Found: $\mathrm{C}$, 55.95; $\mathrm{H}, 4.58 ; \mathrm{N}, 2.65$. Calcd for $\mathrm{C}_{52} \mathrm{H}_{48} \mathrm{~F}_{4} \mid \mathrm{rN}_{2} \mathrm{O}_{3} \mathrm{P}_{3}(1110,10)$ : $\mathrm{C}$, 56.26; $\mathrm{H}, 4.36 ; \mathrm{N}, 2.52 .{ }^{1} \mathrm{H}$ NMR $\left(\mathrm{CDCl}_{3}, 298 \mathrm{~K}\right): \delta=8.21\left(\mathrm{~d},{ }^{2} J_{\mathrm{HP}}\right.$ $=16.6 \mathrm{~Hz}, 2 \mathrm{H}, \mathrm{NH}), 7.80\left(\mathrm{~m}, 4 \mathrm{H}, o-\mathrm{PPh}, \delta_{\mathrm{C}}=132.2\right), 7.41-7.35$ (total 6H: $4 \mathrm{H}, m-\mathrm{PPh}, \delta_{\mathrm{C}}=127.5 ; 2 \mathrm{H}, p-\mathrm{PPh}, \delta_{\mathrm{C}}=129.4$ ), 7.297.23 (total $6 \mathrm{H}: 4 \mathrm{H}, o-\mathrm{PPh}, \delta_{\mathrm{C}}=131.6 ; 2 \mathrm{H}, p-\mathrm{PPh}, \delta_{\mathrm{C}}=129.2$ ), $7.19\left(\mathrm{~m}, 4 \mathrm{H}, m-\mathrm{PPh}, \delta_{\mathrm{C}}=127.9\right), 6.71\left(\mathrm{~d}, 2 \mathrm{H},{ }^{3} J_{\mathrm{HH}}=8.3 \mathrm{~Hz}\right.$, $\left.\mathrm{C}^{3} \mathrm{H}^{\text {tol }}, \delta_{\mathrm{C}}=128.9\right), 6.42\left(\mathrm{~d}, 2 \mathrm{H},{ }^{3} \mathrm{~J}_{\mathrm{HH}}=8.3 \mathrm{~Hz}, \mathrm{C}^{2} \mathrm{H}^{\text {tol }}, \delta_{\mathrm{C}}=118.4\right)$,

"* The coordinated $\mathrm{P}(\mathrm{OMe})_{3}$ is supposed to be in the up semispace of the SiNP ligand and the superscript $\mathrm{d}$, down, and $\mathrm{u}$, up, are used accordingly, see Figure $2 \mathrm{~B}$. 
$4.19\left(\mathrm{~m}, 2 \mathrm{H}, \mathrm{C}^{\mathrm{sp} 3} \mathrm{H}^{\mathrm{tfbb}}, \delta_{\mathrm{C}}=33.3\right), 3.58\left(\mathrm{~d},{ }^{3} J_{\mathrm{HP}}=10.7 \mathrm{~Hz}, 6 \mathrm{H}\right.$, $\left.\mathrm{POCH}_{3}, \delta_{\mathrm{C}}=50.6\right), 2.13\left(\mathrm{~s}, 6 \mathrm{H}, \mathrm{CH}_{3}{ }^{\mathrm{tol}}, \delta_{\mathrm{C}}=20.2\right), 2.49(\mathrm{~m}, 4 \mathrm{H}$, $\left.\mathrm{C}^{\mathrm{sp} 2} \mathrm{H}^{\mathrm{tfbb}}, \delta_{\mathrm{C}}=35.4\right) .{ }^{13} \mathrm{C} \mathrm{NMR}\left(\mathrm{CDCl}_{3}, 298 \mathrm{~K}\right): \delta=139.2\left(\mathrm{C}^{4 \mathrm{tol}}\right)$, $136.7\left(\mathrm{~d},{ }^{2} J_{\mathrm{CP}}=49.5 \mathrm{~Hz}, \mathrm{PC}\right), 135.1\left(\mathrm{~d},{ }^{2} J_{\mathrm{CP}}=50.6 \mathrm{~Hz}, \mathrm{PC}\right), 130.2$ $\left(\mathrm{C}^{1 \text { tol }}\right) .{ }^{19} \mathrm{~F} \mathrm{NMR}\left(\mathrm{CDCl}_{3}, 298 \mathrm{~K}\right): \delta=-148.1(\mathrm{~m}, 2 \mathrm{~F}, \mathrm{tfbb}),-161.0$ (m, 2F, tfbb). ${ }^{31} \mathrm{P}\left\{{ }^{1} \mathrm{H}\right\} \mathrm{NMR}\left(\mathrm{CDCl}_{3}, 298 \mathrm{~K}\right): \delta=43.8\left(\mathrm{t},{ }^{2} \mathrm{JPP}_{\mathrm{PP}}=36.3\right.$ $\left.\mathrm{Hz}, 1 \mathrm{P}, \mathrm{PO}\left(\mathrm{OCH}_{3}\right)_{2}\right), 16.5\left(\mathrm{~d},{ }^{2} J_{\mathrm{PP}}=36.3,2 \mathrm{P}, \mathrm{HNP}\right)$. IR $\left(\mathrm{CHCl}_{3}, 298\right.$ K): $3690\left(v_{\mathrm{NH}}\right), 3316\left(v_{\mathrm{NH}}\right) \mathrm{cm}^{-1}$.

Formation of $\left[\operatorname{Ir}(\mathrm{HNP})_{2}\left\{\mathrm{P}(\mathrm{OMe})_{3}\right\}(\mathrm{tfbb})\right] \mathrm{Cl}$ (5). A solution of $\operatorname{IrCl}(\mathrm{HNP})_{2}$ (tfbb) $\left(13.1 \mathrm{mg}, 12.6 \mu \mathrm{mol}, 1036.51 \mathrm{~g} \cdot \mathrm{mol}^{-1}\right)$ in $\mathrm{CDCl}_{3}$ $(0.4 \mathrm{~mL})$ was cooled at $260 \mathrm{~K}$ and added with $1.5 \mu \mathrm{L}$ of $\mathrm{P}(\mathrm{OMe})_{3}$ (13 $\mu \mathrm{mol}, 124.08 \mathrm{~g} \cdot \mathrm{mol}^{-1}, 1.052 \mathrm{~g} \cdot \mathrm{mL}^{-1}$ ) in a $5-\mathrm{mm}$ NMR tube. The resulting pale yellow solution was transferred to the NMR spectrometer at $260 \mathrm{~K}$. The solution only contained the new compound $\left[\operatorname{Ir}(\mathrm{HNP})_{2}\left\{\mathrm{P}(\mathrm{OMe})_{3}\right\}(\mathrm{tfbb})\right] \mathrm{Cl}([5] \mathrm{Cl})$ which was fully characterised in situ by NMR spectroscopy. ${ }^{1} \mathrm{H}$ NMR $\left(\mathrm{CDCl}_{3}\right.$, $260 \mathrm{~K}): \delta=7.64\left(\mathrm{~m}, 4 \mathrm{H}, o-\mathrm{PPh}^{1}, \delta_{\mathrm{C}}=131.1\right), 7.56-7.40(16 \mathrm{H}$, $\delta_{\mathrm{C}}=131.3, o-\mathrm{PPh}, 130.8, p-\mathrm{PPh}, 130.6, p-\mathrm{PPh}, 128.8, m-\mathrm{PPh}$, 128.6, m-PPh), $6.74\left(\mathrm{~d},{ }^{3} J_{\mathrm{HH}}=8.2 \mathrm{~Hz}, 4 \mathrm{H}, \mathrm{C}^{3} \mathrm{H}^{\text {tol }}, \delta_{\mathrm{C}}=129.3\right)$, $6.57\left(\mathrm{~d},{ }^{2} J_{\mathrm{HP}}=15.1 \mathrm{~Hz}, 2 \mathrm{H}, \mathrm{NH}\right), 6.26\left(\mathrm{~d},{ }^{3} J_{\mathrm{HH}}=8.2 \mathrm{~Hz}, 4 \mathrm{H}, \mathrm{C}^{2} \mathrm{H}^{\text {tol }}\right.$, $\left.\delta_{\mathrm{C}}=118.1\right), 4.02\left(\mathrm{~m}, \mathrm{C}^{\mathrm{sp} 3} \mathrm{H}^{\mathrm{tfbb}}, 2 \mathrm{H}, \delta_{\mathrm{C}}=33.1\right), 3.76\left(\mathrm{~d},{ }^{3} J_{\mathrm{HP}}=11.1\right.$ $\left.\mathrm{Hz}, 9 \mathrm{H}, \mathrm{POCH}_{3}, \delta_{\mathrm{C}}=55.2\right), 2.78\left(\mathrm{~m}, 4 \mathrm{H}, \mathrm{C}^{\mathrm{sp2}} \mathrm{H}^{\mathrm{tfbb}}, \delta_{\mathrm{C}}=38.9\right), 2.14$ $\left(\mathrm{s}, 6 \mathrm{H}, \mathrm{CH}_{3}{ }^{\text {tol }}, \delta_{\mathrm{C}}=20.4\right) .{ }^{13} \mathrm{C} \mathrm{NMR}\left(\mathrm{CDCl}_{3}, 260 \mathrm{~K}\right): \delta=139.2$ $\left(\mathrm{C}^{4 \text { tol }}\right), 130.2\left(\mathrm{C}^{1 \text { tol }}\right) .{ }^{19} \mathrm{~F} \mathrm{NMR}\left(\mathrm{CDCl}_{3}, 260 \mathrm{~K}\right): \delta=-146.2(\mathrm{~m}, 2 \mathrm{~F}$, tfbb), $-158.8(\mathrm{~m}, 2 \mathrm{~F}, \mathrm{tfbb}) .{ }^{31} \mathrm{P}\left\{{ }^{1} \mathrm{H}\right\} \mathrm{NMR}\left(\mathrm{CDCl}_{3}, 260 \mathrm{~K}\right): \delta=76.8$ (br, 1P, P(OMe) $)_{3}$ ), $12.6\left(\mathrm{~d},{ }^{2} J_{\mathrm{PP}}=30.0 \mathrm{~Hz}, 2 \mathrm{P}, \mathrm{HNP}\right)$.

DFT geometry optimization. The molecular structures were optimized at the DFT-BP3LYP level (298 K, 1 atm) using Gaussian09 program. ${ }^{19}$ The LanL2TZ(f) ${ }^{20}$ basis and pseudo potential were used for iridium and the $6-31 G(d, p)$ basis set for the remaining atoms, including diffuse functions for chloro. Stationary points were characterised by vibrational analysis (one imaginary frequency for transition states, only positive frequencies for minimum energy molecular structures). All the structures were optimized in the gas phase and finally the frequencies calculation was carried out in $\mathrm{CH}_{2} \mathrm{Cl}_{2}$ using the CPCM method. The NMR data were calculated using the GIAO method in $\mathrm{CH}_{2} \mathrm{Cl}_{2}$ or $\mathrm{CHCl}_{3}$ ( $\mathrm{CPCM}$ method). Atomic coordinates of calculated structure are given in the ESI.

Solid state structure determinations. Single crystals of $\operatorname{IrCl}(\mathrm{SiNP})(\mathrm{tfbb}) \quad(\mathbf{1}), \quad \operatorname{IrCl}(\mathrm{PNH})_{2}(\mathrm{tfbb}) \quad(2)$, $\left[\operatorname{Ir}(\mathrm{SiNP})\left\{\mathrm{P}(\mathrm{OMe})_{3}\right\}(\mathrm{tfbb})\right] \mathrm{Cl} \quad([3] \mathrm{Cl}), \quad$ and $\operatorname{Ir}\left\{\mathrm{PO}(\mathrm{OMe})_{2}\right\}(\mathrm{PNH})_{2}(\mathrm{tfbb})(4)$ suitable for the $\mathrm{X}$-ray diffraction study were obtained by slow diffusion of hexane or diethyl ether into a dichloromethane or chloroform solution of the compound. Intensities were collected using a Bruker SMART APEX-DUO diffractometer with graphite-monochromated Mo K $\alpha$ radiation $(\lambda=0.71073 \AA$ ) following standard procedures. Intensities were integrated and corrected for absorption effects using the SAINT $+{ }^{21}$ and SADABS ${ }^{22}$ programs, included in the APEX2 package. The structure was solved by the Patterson's method. All non-hydrogen atoms were located in the subsequent Fourier maps. Refinement was carried out by full-matrix least-square procedure (based on $\mathrm{F}_{0}{ }^{2}$ ) using anisotropic temperature factors for all non-hydrogen atoms. Most $\mathrm{C}-\mathrm{H}$ hydrogen atoms were placed in calculated positions with fixed isotropic thermal parameters $\left(1.2 \mathrm{xU}_{\text {equiv }}\right.$ of the parent carbon atom). Calculations were performed with SHELX $-97^{23}$ program implemented in the WinGX package. ${ }^{24}$ Highly disordered hexane molecules in $\mathbf{2} \cdot \mathrm{C}_{6} \mathrm{H}_{14}$ were treated using the program SQUEEZE implemented in Platon. ${ }^{25} \mathrm{~A}$ solvent accesible void volume of $360 \AA^{3}$ was found containing 92 electrons thus suggesting the presence of approximately two crystallization hexane molecules per cell, i.e. one molecule per iridium. The disordered molecules of chloroform in [3] $\mathrm{Cl} \cdot 6 \mathrm{CHCl}_{3}$ and of dichloromethane in $1 \cdot \mathrm{CH}_{2} \mathrm{Cl}_{2}$ were included in the model defining two sets of coordinates for its atoms with complementary occupancy factors and finally including the hydrogen atoms in calculated position and refining them with a riding model. Geometrical restraints (SADI) were applied to the carbon-chlorine bonds.

Geometric parameters of the $\mathrm{N}-\mathrm{H} \cdots \mathrm{O}$ hydrogen bond were obtained using the program PARST $^{26}$ implemented in the WinGX package.

Crystal data of $\operatorname{IrCl}(\operatorname{SiNP})(t f b b) \cdot \mathrm{CH}_{2} \mathrm{Cl}_{2}, \quad \mathbf{1} \cdot \mathrm{CH}_{2} \mathrm{Cl}_{2}$, $\mathrm{C}_{53} \mathrm{H}_{48} \mathrm{Cl}_{3} \mathrm{~F}_{4} \mathrm{IrN}_{2} \mathrm{P}_{2} \mathrm{Si}, M=1177.51 \mathrm{~g} \cdot \mathrm{mol}^{-1}, T=100(2) \mathrm{K}$, triclinic, $P-1, a=10.2012(5) \AA, b=11.3266(5) \AA, c=21.6766(10) \AA, \alpha=$ $81.3430(10)^{\circ}, \quad \beta=87.5760(10)^{\circ}, \quad \gamma=76.0320(10)^{\circ} ; \quad V=$ 2402.82(19) $\AA^{3}, Z=2, D_{\text {calc }}=1.628 \mathrm{~g} \cdot \mathrm{cm}^{-3}, \mu=3.092 \mathrm{~mm}^{-1}$, yellow prism, $0.160 \times 0.150 \times 0.050 \mathrm{~mm}, \theta$ range for data collection: $1.872^{\circ}$ to $28.629^{\circ}$; limiting indices: $-13 \leq h \leq 13$, $15 \leq k \leq 15, \quad-27 \leq l \leq 27$, reflections collected/unique: 38667/11361 $[R($ int $)=0.0383]$, data/restraints/parameters: $1361 / 6 / 651, \mathrm{GOF}=1.031, R_{1}=0.0280[/>2 \sigma(I)], 0.0355$ (all data); $w R_{2}=0.0559[/>2 \sigma(/)], 0.0591$ (all data). CCDC deposit number 1431019

Crystal data of $\operatorname{IrCl}(H N P)_{2}(t f b b) \cdot C_{6} H_{14}, \mathbf{2} \cdot \mathrm{C}_{6} \mathrm{H}_{14}, \mathrm{C}_{56} \mathrm{H}_{56} \mathrm{ClF}_{4} \mid \mathrm{rN}_{2} \mathrm{P}_{2}$, $M=1122.61 \mathrm{~g} \cdot \mathrm{mol}^{-1}, T=150(2) \mathrm{K}$, triclinic, $P-1, a=$ $12.7613(17) \AA, b=14.3574(19) \AA, c=15.256(2) \AA, \alpha=$ $65.898(2)^{\circ}, \beta=70.205(2)^{\circ} . \gamma=81.373(2)^{\circ}, V=2400.5(6) \AA^{3}, Z=$ 2, $D_{\text {calc }}=1.553 \mathrm{~g} \cdot \mathrm{cm}^{3}, \mu=2.960 \mathrm{~mm}^{-1}$, yellow prism, $0.090 \mathrm{x}$ $0.090 \times 0.070 \mathrm{~mm}, \theta$ range for data collection: $1.537^{\circ}$ to $26.372^{\circ}$, limiting indices: $-15 \leq h \leq 15,-17 \leq k \leq 17$, $19 \leq I \leq 19$, reflections collected/unique: $25339 / 9782[R($ int $)=$ 0.0481], data/restraints/parameters: 9782/3/551, GOF = $0.985, R_{1}=0.0336[l>2 \sigma(l)], 0.0459$ (all data), $w R_{2}=0.0663$ [I > 2o(I)], 0.0706 (all data). CCDC deposit number 1431038. Crystal data of $[$ Ir(SiNP $\left.)\left\{P(O M e)_{3}\right\}(t f b b)\right] C l \cdot 6 \mathrm{CHCl}_{3}$, [3] Cl. $6 \mathrm{CHCl}_{3}, \mathrm{C}_{61} \mathrm{H}_{61} \mathrm{Cl}_{19} \mathrm{~F}_{4} \mid \mathrm{rN}_{2} \mathrm{O}_{3} \mathrm{P}_{3} \mathrm{Si}, M=1932.86 \mathrm{~g} \cdot \mathrm{mol}^{-1}, T=$ 210(2) K, monoclinic, $\mathrm{P} 2_{1} / \mathrm{n}, a=13.1710(16) \AA, b=15.823(2) \AA$, $c=38.136(5) \AA, \beta=98.969(2)^{\circ}, V=7850.7(17) \AA^{3}, Z=4, D_{c a l c}=$ $1.635 \mathrm{~g} \cdot \mathrm{cm}^{3}, \mu=2.476 \mathrm{~mm}^{-1}$, yellow prism, $0.250 \times 0.140 \mathrm{x}$ $0.060 \mathrm{~mm}, \theta$ range for data collection: $1.396^{\circ}$ to $27.102^{\circ}$, limiting indices: $-16 \leq h \leq 16,-20 \leq k \leq 20,-48 \leq I \leq 45$, reflections collected/unique: $82649 / 17319[R($ int $)=0.0653]$, data/restraints/parameters: $17319 / 12 / 848, \mathrm{GOF}=1.029, R_{1}=$ $0.0504[I>2 \sigma(I)], 0.0756$ (all data), $w R_{2}=0.1269[I>2 \sigma(I)]$, 0.1397 (all data). CCDC deposit number 1430994 .

Crystal data of $\operatorname{Ir}\left\{\mathrm{PO}(\mathrm{OMe})_{2}\right\}(\mathrm{HNP})_{2}(t f b b), 4, \mathrm{C}_{52} \mathrm{H}_{48} \mathrm{~F}_{4} \mathrm{IrN}_{2} \mathrm{O}_{3} \mathrm{P}_{3}$, $M=1110.03 \mathrm{~g} \cdot \mathrm{mol}^{-1}, T=100(2) \mathrm{K}$, triclinic, $P-1, a=11.316(3)$ $\AA$, $b=12.460(3) \AA, c=18.790(5) \AA, \alpha=84.494(3)^{\circ}, \beta=$ $76.042(3)^{\circ}, \gamma=64.907(3)^{\circ}, V=2328.5(10) \AA^{3}, Z=2, D_{\text {calc }}=$ $1.583 \mathrm{~g} \cdot \mathrm{cm}^{-3}, \mu=3.032 \mathrm{~mm}^{-1}$, yellow prism, $0.170 \times 0.150 \mathrm{x}$ $0.100 \mathrm{~mm}, \theta$ range for data collection: $1.805^{\circ}$ to $26.372^{\circ}$, limiting indices: $-13 \leq h \leq 14, \quad-15 \leq k \leq 15, \quad-23 \leq l \leq 23$, 
reflections collected/unique: 21178/9490 $[R($ int $)=0.0257]$, data/restraints/parameters: $9490 / 2 / 622$, GOF $=1.034, R_{1}=$ $0.0250[I>2 \sigma(I)], 0.0274$ (all data), $w R_{2}=0.0601[I>2 \sigma(I)]$, 0.0612 (all data). CCDC deposit number 1431055

\section{ABBREVIATIONS}

$\begin{array}{ll}\begin{array}{l}\text { cod } \\ \text { ct }[X-Y]\end{array} & \begin{array}{l}\text { c,5-cyclooctadiene } \\ \text { centroid of the } \mathrm{C}(\mathrm{X})-\mathrm{C}(\mathrm{Y}) \text { bond }\end{array} \\ \mathrm{HNP} & \mathrm{NH}\left(4-\mathrm{C}_{6} \mathrm{H}_{4} \mathrm{CH}_{3}\right) \mathrm{PPh}_{2} \\ \mathrm{SiNP} & \mathrm{Si}\left(\mathrm{CH}_{3}\right)_{2}\left\{\mathrm{~N}\left(4-\mathrm{C}_{6} \mathrm{H}_{4} \mathrm{CH}_{3}\right) \mathrm{PPh}_{2}\right\}_{2} \\ \text { tfbb } & \text { tetrafluorobenzobarrelene }\end{array}$

\section{AUTHOR INFORMATION}

\section{Corresponding author}

* Tel. +34 976 739863. E-mail: passarel@unizar.es

\section{ACKNOLEDGEMENTS}

Financial support from Spanish "Ministerio de Economía y Competitividad" (MINECO/FEDER, CTQ2013-42532-P) and "Diputación General de Aragón" (DGA/FSE-E07) is gratefully acknowledged.

\section{REFERENCES}

1 Bifunctional Molecular Catalysis, in, Topics in Organometallic Chemistry, vol. 37, Takao Ikariya and Masakatsu Shibasaki, Eds., Springer Berlin Heidelberg, 2011.

2 (a) R. Noyori, C. A. Sandoval, K.Muñiz and T. Ohkuma, Phil. Trans. R. Soc. A, 2005, 363, 901; (b) R. Noyori, M. Yamakawa and S. Hashiguchi, J. Org. Chem., 2001, 66, 7931; (c) R. H. Morris, Acc. Chem. Res., 2015, 48, 1494; (d) J. I. van der Vlugt, Eur. J. Inorg. Chem., 2012, 363; (e) T. Ikariya, Bull. J. Soc. Jpn., 2011, 84, 1; (f) S. Kuwata and T. Ikariya, Chem. Commun., 2014, 50, 14290.

3 N. Meier, F. E. Hahn, T. Pape, C. Siering and S. R. Waldvogel, Eur. J. Inorg. Chem., 2007, 1210.

4 K. Araki, S. Kuwata and T. Ikariya, Organometallics, 2008, 27, 2176.

5 (a) V. Passarelli, J. J. Pérez-Torrente and L. A. Oro, Inorg. Chem., 2014, 53, 972; (b) V. Passarelli, J. J. Pérez-Torrente and L. A. Oro, Dalton Trans., 2015, DOI: 10.1039/C5DT02886H.

6 A. W. Addison, T. Nagewara Rao, J. Reedijk, J. van Rijn and G. C. Vershoor, J. Chem. Soc., Dalton Trans., 1984, 1349.

7 Nomenclature of Inorganic Chemistry. IUPAC Recommendations 2005; Connely, N. G., Damhus, T., Eds.; Royal Society of Chemistry: Cambridge, 2005.

8 For instance see: T. Makino, Y. Yamamoto and K. Itoh, Organometallics, 2004, 23, 1730; T. Shibata, K. Yamashita, H. Ishida and K. Takagi, Org. Lett., 2001, 3, 1217.

9 J. A. Casares, P. Espinet, J. M. Martín-Alvarez, G. Espino, M. Pérez-Manrique and F. Vattier, Eur. J. Inorg. Chem., 2001, 289.

10 V. Passarelli and F. Benetollo, Inorg. Chem., 2011, 50, 9958.

11 M. Valderrama and R. Contreras, J. Organomet. Chem., 1996, 513, 7.

12 M. Vaderrama, J. Cuevas, D. Boys, D. Carmona, M. P. Lamata, F. Viguri, R. Atencio, F. J. Lahoz and L. A. Oro, J. Chem. Soc., Dalton Trans., 1996, 2877.
13 See CCDC ( $a$ ) refcode ONEZAJ in A. Christiansen, D. Selent, A. Spannenberg, M. Kockerling, H. Reinke, W. Baumann, H. Jiao and R. Franke, Chem.-Eur. J., 2011, 17, 2120; (b) refcode RAXMIM in C. G. Arena, F. Nicolo, D. Drommi, G. Bruno and F. Faraone, J. Chem. Soc., Dalton Trans., 1996, 4357; (c) refcode IXADAM in D. M. Tooke, A. M. Mills, A. L. Spek and J. I. van der Vlugt, Acta Crystallogr., Sect. E. Struct. Rep. Online, 2004, 60, m943.

14 (a) A. Whuler, C. Brouty and P. Spinat, Acta Cryst., 1980, B36, 1267; (b) R. Taylor, O. Kennard and W. Versichel, Acta Cryst., 1984, B40, 280; (c) R. Taylor, O. Kennard and W. Versichel, J. Am. Chem. Soc., 1983, 105, 5761.

15 See CCDC (a) refcodes AFASAC and AFASEG in H. Krishna, S. S. Krishnamurthy, M. Nethaji, R. Murugavel and G. Prabusankar, Dalton Trans., 2007, 2908; $(b)$ refcode BINXEC in M. S. Balakrishna, P. P. George and J. T. Mague, J. Organomet. Chem., 2004, 689, 3388, (c) refcode GESXEH in H. Brunner, C. R. Jablonski and P. G. Jones, Organometallics, 1988, 7, 1283; (d) refcode GOXYUN in M. Ganesan, S. S. Krishnamurthy and M. Nethaji, J. Organomet. Chem., 1998, 570, 247, (e) refcode KUMPEN in C. R. Jablonski, $\mathrm{H}$. Ma and R. C. Hynes, Organometallics, 1992, 11, 2796, (f) refcode VASTEO in C. Jablonski, T. Burrow and P. G. Jones, J. Organomet. Chem., 1989, 370, 17.

16 For comparison, relevant NMR data for $\mathrm{CH}_{3} \mathrm{Cl}$ are given in $\mathrm{M}$. E. O'Reilly, D. R. Pahls, J. R. Webb, N. C. Boaz, S. Majumdar, C. D. Hoff, J. T. Groves, T. R. Cundari and T. B. Gunnoe, Dalton Trans., 2014, 43, 8273.

17 Selected references are: (a) T. B. Brill and S. J. Landon, Chem. Rev., 1984, 84, 577; (b) Z. Chen, C. Jablonski and J. Bridson, Can. J. Chem., 1996, 2083.

18 R. Usón, L. A. Oro, D. Carmona and M. A. Esteruelas, J. Organomet. Chem., 1983, 254, 249.

19 M. J. Frisch et al. Gaussian 09 (Revision A.02); Gaussian, Inc. Wallingford, CT, 2009.

20 L. E. Roy, P. J. Hay and R. L. Martin, J. Chem. Theory Comput., 2008, 4, 1029.

21 SAINT+, version 6.01; Bruker AXS, Inc.; Madison, WI, 2001.

22 G. M. Sheldrick, SABADS, University of Göttingen: Göttingen, Germany, 1999.

23 (a) G. M. Sheldrick, SHELXL-97, University of Göttingen: Göttingen, Germany, 1997; (b) G. M. Sheldrick, Acta Crystallogr., 2008, A64, 112.

24 L. J. Farrugia, J. Appl. Crystallogr., 1999, 32, 837.

25 P. v. d. Sluis and A. L. Spek, Acta Crystallogr., C, 1990, A46, 194.

26 M. Nardelli, J. Appl. Cryst., 1995, 28, 659 (Release Nov. 1999). 